\title{
THE LACEWINGS (INSECTA, NEUROPTERA) OF TASMANIA
}

\author{
by T.R. New
}

\author{
(with 138 text-figures)
}

\begin{abstract}
NEW, T.R., 1992 (31:x): The lacewings (Insecta, Neuroptera) of Tasmania. Pap. Proc. R. Soc. Tasm. 126: $29-45$. ISSN 008-4703. https://doi.org/10.26749/rstpp.126.29 Department of Zoology, La Trobe University, Bundoora, Victoria, Australia 3083.
\end{abstract}

A synopsis is given, with keys provided før identification, of the $\mathbf{4}$ species of Neuroptera known from Tasmania and the Bass Strait Islands. Nine families are represented; the Australian mainland families Neurorthidae, Berothidae, Psychopsidae, Nemopteridae and Ascalaphidae have not been recorded. A family-level key to larvae is given. Notes on the biology and distribution of all species are provided. Endemism is low, and only two species, Kempynus longipennis (Walker) and Dictyochrysa latifascia Kimmins, are believed to be restricted to the State; most other species are widespread in southeastern Australia or more widely distributed.

Key Words: lacewings, Neuroptera, Tasmania, key, insects, distribution.

\section{INTRODUCTION}

Neuroptera, or Planipennia, are amongst the most primitive groups of endopterygote insects and occur in most temperate and tropical parts of the world. The order includes around 5000 described species of the taxa, commonly known as "lacewings", "dusty wings", "sponge-flies", "owl-flies", "antlions" and others. They are thus diverse in appearance, and specialists are not yet fully agreed about the relationships between the various families.

Adults are so diverse that unifying features between all families are difficult to find. A closer relationship is demonstrated by the larvae. Larvae have suctorial mouthparts in which the mandible and maxilla of each side are usually elongated and closely associated to form a sucking tube. Larvae of many species are unknown, but at least fragmentary data are available on most families - only for the unusual oriental family Rapismatidae are no larval details known.

Neuroptera are included in the superorder Neuropteroidea, together with the Megaloptera (alderflies, dobsonflies) and Raphidioptera (snake-flies: not in Australia). The latter groups are sometimes included in the Neuroptera but are now most commonly considered to constitute distinct orders; their larvae have chewing mouthparts and, thus, differ clearly from those of Neuroptera s. str. The ordinal name "Planipennia" is commonly applied to this restricted complement of the Neuroptera.

Both adults and larvae of the various families are, for the most part, very distinctive. The form of the egg may also be characteristic at this level.

Most recent Neuroptera are terrestrial, and the two families with truly aquatic larvae constitute only minor components of typical freshwater faunas. The terrestrial taxa fall into two major ecological groupings: (1) those in which larvae are almost always found on vegetation, where they feed on a range of small, soft-bodied arthropods, such as aphids, scale insects and psyllids (lerp insects); (2) ground-dwelling forms which may even be subterranean and spend much of their time buried in sand, soft soil or litter. Others are predominantly cortical or subcortical and, as with some grounddwellers, may emerge from their "retreats" to forage more actively by night. Rarely (Mantispidae) larvae have an obligate "parasitic" relationship with spider egg cases and are found only in association with such specialised habitats. Freeliving larvae of several families habitually cover themselves with debris, including sand, vegetable fragments and lichens, or remains of prey organisms.

Eggs are laid on vegetation or more casually scattered on/ in soil, singly or in batches of varying sizes - the particular oviposition pattern usually being very characteristic of given taxa. Eggs of most families are cemented directly to the substrate, but those of Chrysopidae, Mantispidae, Berothidae and Nymphidae are stalked. Hatching occurs by the use of an oviruptor, or by removal of a circular cap via a predetermined "line of weakness" in the chorion. Eggs are generally not ornamented, although those of some Osmylidae have prominent chorionic projections and a well-defined micropyle. There are normally three larval instars, and pupation occurs within a silken cocoon from which the decticous pupa emerges (or partially emerges) before the final moult to adult stage.

As with many other groups of little-studied insects, detailed ecological information on particular species is only rarely available. The most intensively studied Neuroptera are those which have been valued as predators in biological control programmes - especially the green lacewings (Chrysopidae) (Canard et al. 1984), the brown lacewings (Hemerobiidae) and, to a much lesser extent, the dusty-wings (Coniopterygidae).

Riek (1970) noted only seven species of Neuroptera from Tasmania, out of a total of 396 Australian species. Since then, considerable taxonomic work has been undertaken on the Australian fauna, and the revised edition of The Insects of Australia notes that 623 Australian species have now been recognised (New 1991). Endenicity is very high, with well over $90 \%$ of Australian lacewings not yet known from elsewhere. The minimum number of Tasmanian species is now 40, and additions are likely in, especially, Coniopterygidae and Sisyridae, in which undescribed and poorly documented species occur. Neither has been the subject of a major revision in recent years, although Meinander's (1972) monograph of Coniopterygidae included all Australian species then known. With the exception of these families, however, a reasonably accurate or informed account of the Tasmanian fauna is now feasible. No faunal account should ever be considered to be fully definitive, but records such as the present can serve to provide a reference point protem and stimulate interest towards further, more detailed documentation, and indicate the areas needing more intensive concentration. Nine of the 14 lacewing families in 
Australia have now been confirmed from Tasmania, although there are very few records of some of these.

In general, the Tasmanian Neuroptera represent an attenuation of the mainland Australian fauna, and a number of the species present are limited to the eastern Bassian province. Others are widespread on the mainland. Only two species, an archaic chrysopid and an osmylid, are at present believed to be wholly endemic to Tasmania. Both belong to endemic Bassian genera and have close relarives in sourheastern Australia. Relatively few species seem to be common in the state, and a few early records are anomalous and have now been confirmed by more recent collecting. Several families occurring in Victoria and other parts of south or eastern Australia have not yet been found in Tasmania but may be genuinely absent. Nemopteridae, confined to semi-arid and arid regions, are not likely to occur there. The same is true of Berothidae, and it is unlikely that such large conspicuous insects as Ascalaphidae and Psychopsidae would have escaped detection in Tasmania, although particular species occur in Victoria and South Australia. In contrast, Neurorthidae may well have been overlooked. Their distinctive larvae are not uncommon in cold streams in Victoria, but the adults are only rarely collected. They should be sought in similar habitats to Sisyridae and some Osmylidae. Several of these families are included in the following keys and brief notes are provided to alert the reader's attention to their possible presence. Very few Neuroptera have been recorded from Bass Strait islands. Comments on the broader distribution of the various Tasmanian taxa are included below, and names of all taxa not actually recorded from the state are indicated by an asterisk. Detailed distribution records for most of the species in Tasmania are premature, as the small amount of specialist collecting inevitably renders existing data very incomplete, but general comments are given where possible.

\section{IDENTIFICATION}

The following keys incorporare a range of structural characrers. They have been designed on a rather broader basis than for the Tasmanian fauna alone, as those to family level for adults and late instar larvae both include several families which are not known from Tasmania but occur elsewhere in southeastern Australia and could possibly occur in the state. At this level, the groups are recognisable on gross features, there is no need for dissection, and a good hand lens or low-power binocular microscope will be adequate for examination. Use of keys to members of each family, in which selected non-Tasmanian taxa are also included, sometimes necessitates close examination of particular adult features, especially those of wing venation and genitalic structures. Larvae cannot be identified confidently beyond family level, as most have now been clearly associated with adults of particular species by rearing.

Wing venation can normally be examined adequately on preserved specimens. The patterns of the various families are very distinct, and it is sometimes difficult to reconcile superficially the venation of one family with that of even closely-related others. Coniopterygidae have relatively simplified venation, but it is more complex in other families. Nomenclature used follows that in recent taxonomic accounts. Many body features, likewise, are discernible without dissection. In some instances, it may be necessary to examine genitalic structure for specific identification.

Taxa not recorded from Tasmania are indicated by an asterisk $\left(^{*}\right)$.

\section{CHECKLIST OF TASMANIAN NEUROPTERA}

Full synonymies of all taxa are listed in the works cited in the "References".

Family Coniopterygidae

Cryptoscenea australiensis (Enderlein)

Neosemidalis (Leucosemidalis) farinosa (Enderlein)

$N$. (Neosemidalis) nervalis Meinander

Coniopteryx (Xeroconiopteryx) maculithorax Enderlein

Heteroconis nigripennis Meinander

Family Ithonidae

Ithone pallida (Tillyard)

Family Osmylidae

Kempynus longipennis (Walker)

Stenosmylus tenuis (Walker)

Oedosmylus tasmaniensis Krüger

$O$. latipennis Kimmins

Family Mantispidae

Calomantispa venusta Lambkin

Campion rubellus Navas

C. tenuistriga (Gerstaecker)

C. australasiae (Guerin)

C. cruciferus (Navas)

C. impressus (Navas)

C. callosus Lambkin

Family Sisyridae

Sisyra spp.
Family Hemerobiidae Psychobiella sordida (Banks)

Psectra nakaharai New

Notherobius nothofagi New

Micromus tasmaniae (Walker)

Drepanacra binocula (Newman)

Megalomina berothoides (McLachlan)

Zachobiella submarginata Esben-Petersen

Family Chrysopidae

Dictyochrysa latifascia Kimmins

D. peterseni Kimmins

Nothancyla verreauxi Navas

?Ankylopteryx immaculata Brauer

Italochrysa insignis (Walker)

Apertochrysa edwardsi (Banks)

Mallada signata (Schneider)

M. tripunctata (McLachlan)

Family Nymphidae

Nymphes myrmeleonides Leach

Family Myrmeleontidae

Myrmeleon acer Walker

Glenoleon falsus (Walker)

Mossega indecisa Banks

Escura australis (Esben-Petersen)

Bandidus vafer (Walker)

Heoclisis fundata (Walker) 


\section{KEY TO FAMILIES: ADULTS}

1 Very small insects, fore wing length to about $4 \mathrm{~mm}$, usually less; usually white or grey, due to wings and much of body being covered with waxy secretion; costal area with, at most, one or two basal crossveins (fig. 5) ........... Coniopterygidae

- $\quad$ Larger, not waxy; costal area with more numerous crossveins

2(1) Fore legs raptorial, femur strongly thickened and spined; prothorax greatly elongated (fig. 1) .......... Mantispidae

- Fore legs not raptorial; prothorax relatively short

* Ascalaphidae

3(2) Antennae strongly clubbed, at least half of fore wing length .....

Antennae usually filiform or moniliform, sometimes with apex gradually broadened: if incipiently clubbed, much shorter than half fore wing length

4(3) Short, stout body; hind wing very broad at base (dark greyish brown, mothlike) (fig. 4). Ithonidac

- Not as above: if body stout (rare), hind wing no broader than fore wing at base. .5

5(4) Antennae distinctly thickened distally, or incipiently clubbed; wings rather narrow (fig. 3)......... Myrmeleontidae

- Antennae not as above : if thickened, uniform along length

6(5) Fore wing vein Sc fused distally with $\mathrm{R}_{1}$ and $\mathrm{Rs}$ to form "vena triplica"; these three veins running closely parallel

- Not as above: "vena triplica" not formed

*Psychopsidae

$7(6)$ Ocelli present, at least represented by raised tubercles on vertex (usually moderately large, brown-winged species) Ocelli absent

Osmylidae

8(7) Veins Sc and $\mathrm{R}_{1}$ fused apically for considerable distance; fore wing vein CuA usually forming large convex enclosed triangular area .......................................................................................... Nymphidae Veins $\mathrm{Sc}$ and $\mathrm{R}_{1}$ linked by crossvein towards apex; fore wing vein CuA not as above

9(8) Fore wing with at least two apparent Rs veins arising from vein $\mathrm{R}$ Hemerobiidae

- $\quad$ Fore wing with only single Rs, arising from vein $\mathrm{R}$ near base

10(9) Hind wing vein CuA not running close to hind margin for at least half wing length; venation of both wings somewhat reticulate (medium to large species, fore wing usually at least $10 \mathrm{~mm}$, brown or green) (fig. 2)

Hind wing vein CuA running close to hind margin usually for at least half wing length (small, brown species, fore wing length to about $7 \mathrm{~mm}$ )

11(10) Fore wing costal crossveins simple (fig. 84) Sisyridae

- $\quad$ Some fore wing costal crossveins forked (fig. 38 ) * Neurorthidae
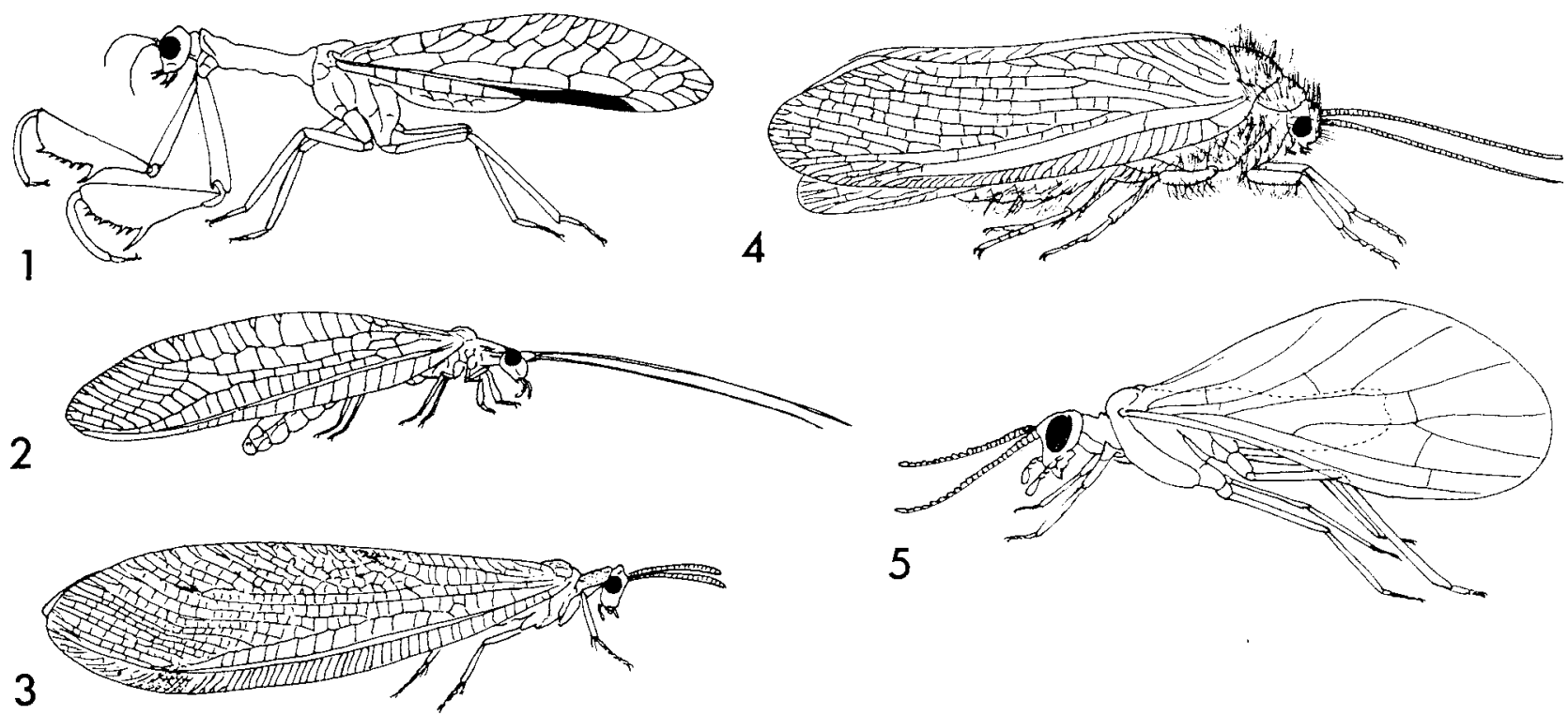

FIGS 1-5 - Representative lacewings, lateral aspect: 1, Mantispidae; 2, Chrysopidae; 3, Myrmeleontidae; 4, Ithonidae; 5, Coniopterygidae. 

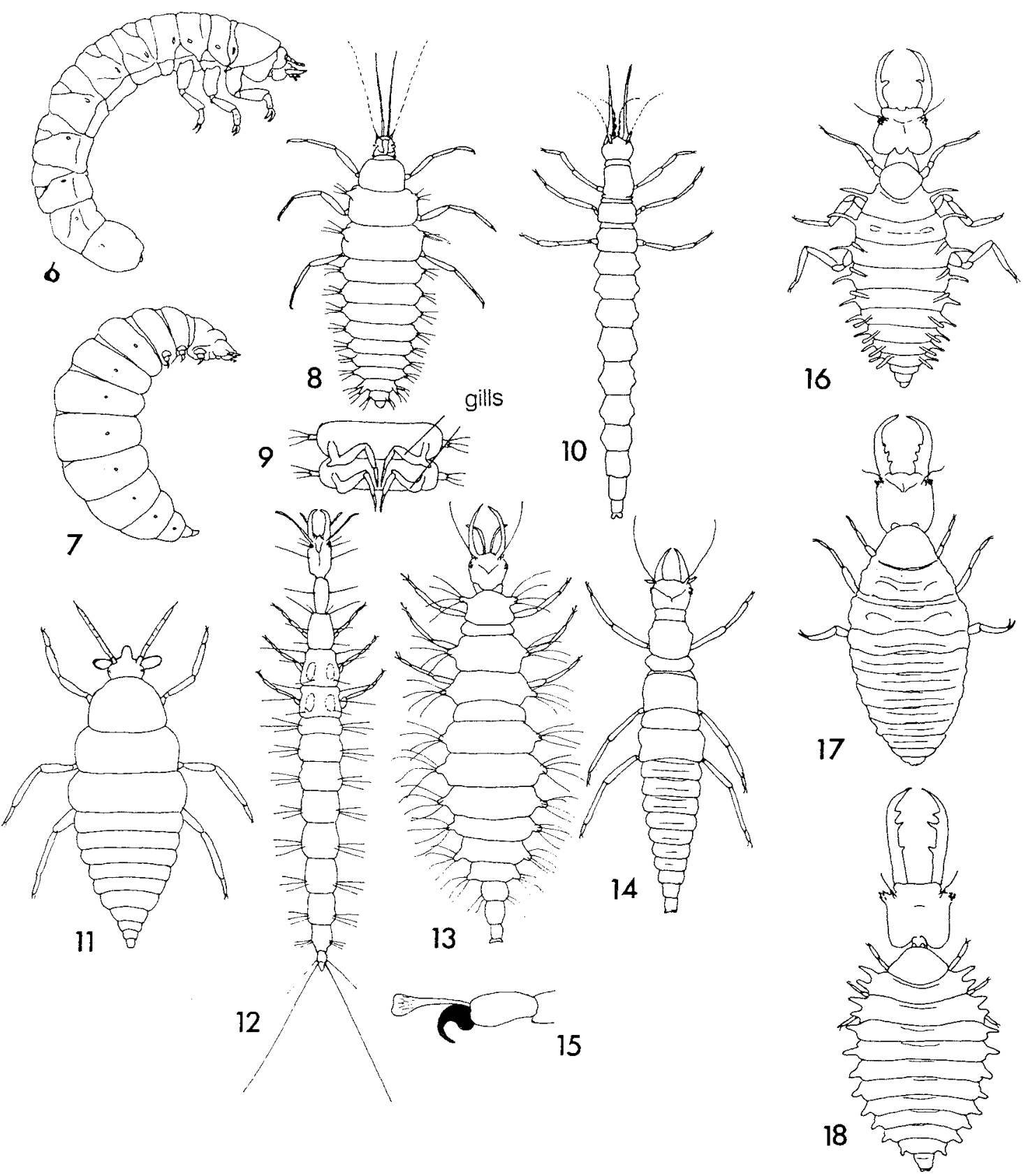

FIGS 6-18 - Lacewing larvae, to indicate general appearance - note varying forms of body and mouthparts: 6, Ithonidae; 7, Mantispidae; 8, Sisyridae; 9, same, ventral, two abdominal segments to show gills; 10, Osmylidae; 11, Coniopterygidae; 12, Neurorthidae; 13, Chrysopidae; 14, Hemerobiidae; 15, empodium of Chrysopidae; 16, Nymphidae, Nymphes; 17, Myrmeleontidae, Myrmeleon; 18, Ascalaphidae. (6, 7, lateral; 8, 10-14, 16-18 dorsal aspect.) 


\section{KEY TO FAMILIES: LATE INSTAR LARVAE}

1 Abdomen with seven pairs of ventral gills; labial palpi absent, mouthparts very long and slender (aquatic) (figs 8,9$)$ Sisyridae

No ventral abdominal gills; labial palpi present, mouthparts not as above (usually terrestrial) ..........................2

2(1) Labial palpi and antennae both 2-segmented; very small, body length usually 2-3 mm (fig. 11)

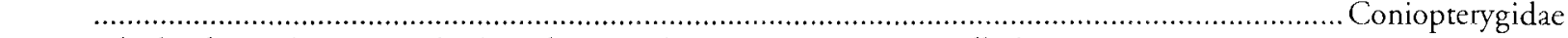

- Labial palpi and antennae both with more than two segments; usually larger ........................................ 3

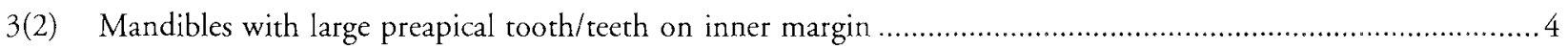

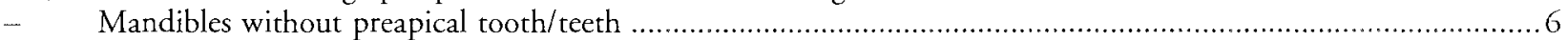

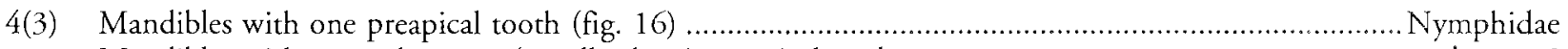

- Mandibles with more than one (usually three) preapical teeth ...............................................................

5(4) Lateral body processes weakly developed, often virtually absent - at least along abdomen; hind tarsal claws flexed forwards and enlarged; hind margin of head not strongly lobed (fig. 17) ........................ Myrmeleontidae Lateral body processes well-developed, usually two each on mesothorax and metathorax and one on each of (at least) first seven abdominal segments; hind tarsal claws normal; hind margin of head strongly bilobed (fig. 18) .. *Ascalaphidae

6(3) Body scarabaeiform; tibiae and tarsi fused; eyes absent (fig. 6) Ithonidae Body generally now scarabaeiform; tibiae and tarsi separate; eyes present .7

7(6) Tarsi with one claw; mandibles very short ("parasitic" in spider egg sacs) (fig. 7) Mantispidae

- Tarsi with two claws; mandibles long (freeliving)

8(7) Mandibles and maxillae inwardly curved from base 9

- Mandibles and maxillae straight or, rarely, inwardly curved at apex..... 11

9(8) Frons tapered anteriorly; dorsal surface of head and thorax with dense, short papillae; no longer setae (subcortical) *Psychopsidae

- $\quad$ Frons not as above; usually with distinct setae on head, thorax or abdomen, or bare (lacking setae and papillae) (usually exposed on vegetation)

10(9) Empodium trumpet-shaped (fig. 15); thorax and abdomen often with long setae (fig. 13) Chrysopidae

- Empodium now trumpet-shaped; thorax and abdomen with short setae, sometimes almost bare (fig. 14). Hemerobiidae

11 (8) Mandibles and maxillae straight (fig. 10) Osmylidae

- Mandibles and maxillae inwardly curved at apex (fig. 12) (aquatic)... Neurorthidae

N.B. For the most part, the above key will work also for earlier instars. Exceptions are: (A) first instar Sisyridae have poorly-developed gills, but the mouthparts are distinctive; (B) first instar Hemerobiidae have the empodium trumpet-shaped and are virtually identical to Chrysopidae; however, Hemerobiidae lay unstalked eggs and those of Chrysopidae in Australia are invariably stalked; (C) first instar Mantispidae differ substantially from later stages in being active triungulinoid larvae, and freeliving. 

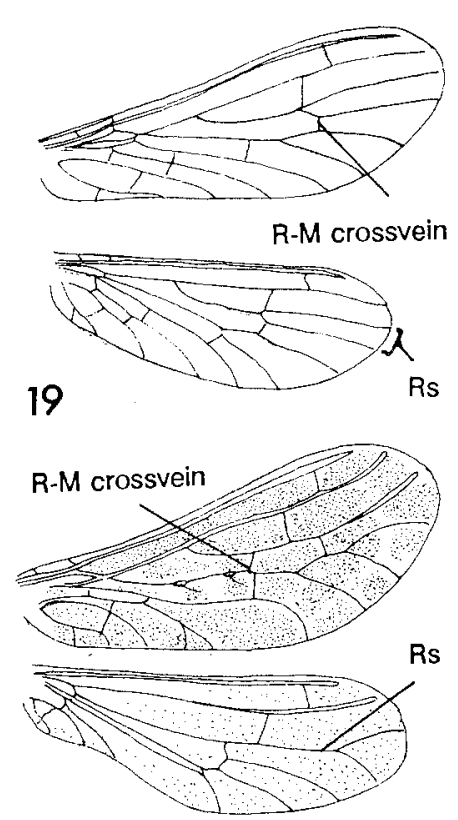

20
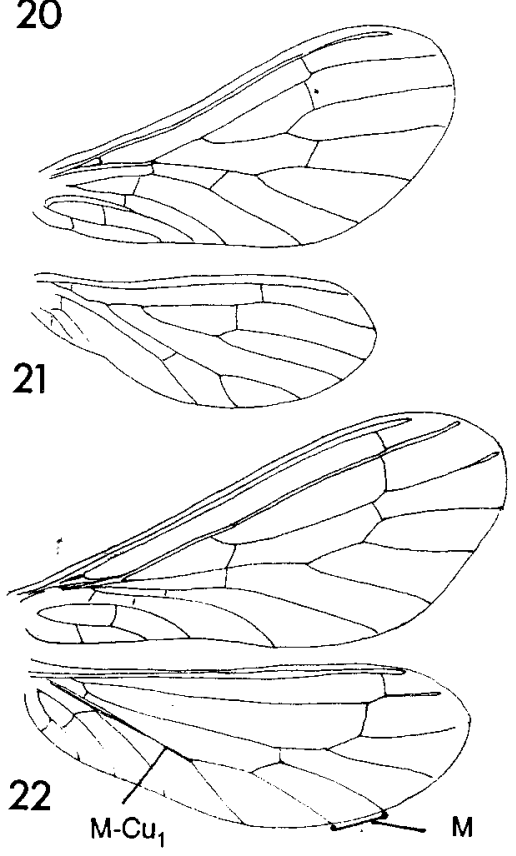

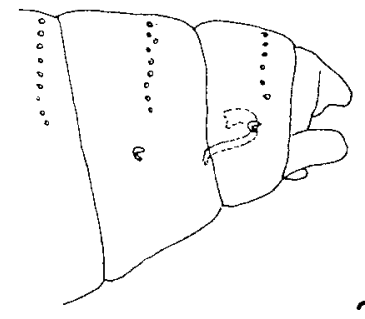

23

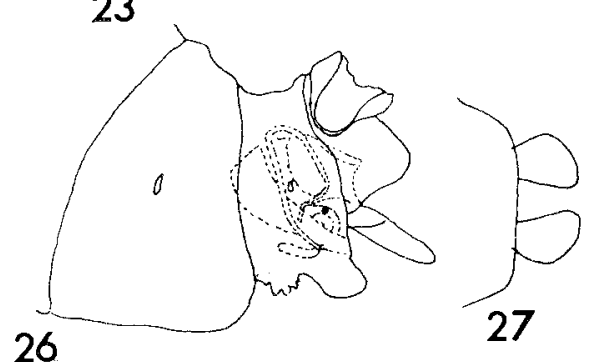

26
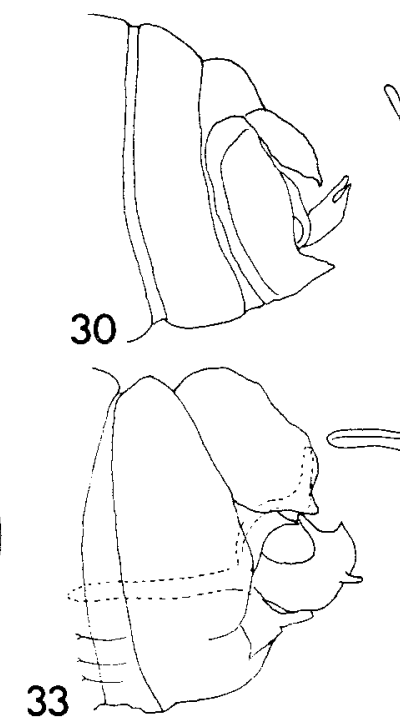

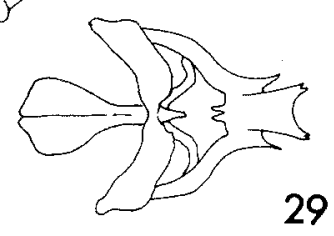

32

25

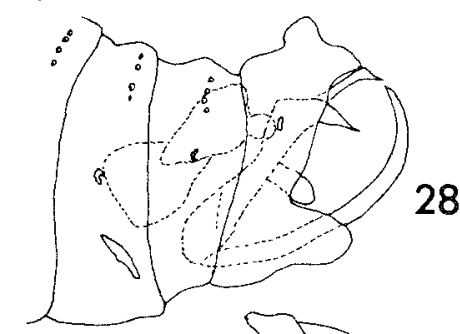

28

FIGS 19-36 - Coniopterygidae: fore and hind wings: 19, Neosemidalis sp.; 20, Heteroconis nigripennis; 21, Coniopteryx sp.; 22, Cryptoscenea australiensis: genitalic structures : 23-25, Cryptoscenea australiensis (23, female, apex of abdomen, lateral; 24, male, same; 25, male, extruded genitalia, ventral); 26-29, Heteroconis nigripennis (26, female, apex of abdomen, lateral; 27, gonapophyses, ventral; 28, male, apex of abdomen, lateral; 29, male, internal genitalic complex, dorsal); 30-32, Coniopteryx maculithorax, male (30, apex of abdomen, lateral; 31, gonarcus and stylus (upper diagram) and paramere (lower diagram), lateral; 32, hypandrium, ventral); 33, 34, Neosemidalis farinosa, male (33, apex of abdomen, lateral; 34, internal genitalia, lateral); $35,36, \mathrm{~N}$. nervalis, male (35, apex of abdomen, lateral; 36 , internal genitalia, lateral). 


\section{SYNOPSIS OF TAXA}

Illustrations provided to aid identifications are simplified to outline drawings, except for some heavily patterned wings; setae are generally omitted to aid clarity of interpretation. More detailed descriptions are given in the revisionary papers cited for each family.

\section{Coniopterygidae}

An isolated family with no close relatives. Cosmopolitan, with about 50 known Australian species. Five have been recorded from Tasmania, and others are likely to occur. The world fauna was monographed by Meinander (1972, 1990), and the most recent synopsis of the Australian species is his 1972 account.

Coniopterygidae, dusty wings, are by far the smallest lacewings. Few are more than $3 \mathrm{~mm}$ in wing length, and they generally appear white or pale grey, although some have distinctive black markings on the forewing, which become more visible after wax is removed by alcohol storage. They can easily be mistaken for white flies (Homoptera) and are predominantly arboreal. Adults are often beaten from trees and shrubs, and only more rarely swept from low vegetation.

Two major subfamilies occur, both represented in Tasmania.

1 Fore wing with $1 \mathrm{R}-\mathrm{M}$ crossvein, near centre of wing (fig. 21); hind wing vein Rs not arising from $R$ near base of wing (fig. 21) ............................. Coniopteryginae

- Fore wing with 2 R-M crossveins (fig. 20); hind wing vein Rs arising near wing base (fig. 20) ....

Aleuropteryginae

\section{Coniopteryginae}

1 Hind wing vein $M$ simple, not forked ..... Coniopteryx - Hind wing vein $M$ forked.... (Neosemidalis).2

2(1) Wings grey, sparsely covered with wax grains

Wings hyaline, with thick coating of wax s.g. Neosemidalis s.g. Leucosemidalis.

\section{Coniopteryx Curtis}

A worldwide genus, with subgenera and species separable mainly on details of male genitalia. The single recorded Tasmanian species, C. (Xeroconiopteryx) maculithorax Enderlein (figs 30-32), belongs to a small group of Australian species characterised by having forked styli (fig. 31). It is widely distributed in Tasmania and eastern mainland Australia $(\mathrm{Q}, \mathrm{NSW}, \mathrm{V})$. Other species in this group are C. occidentalis Meinander (WA, Q, NSW), C. orientalis Meinander $(Q$, NSW) and $C$. tillyardi Meinander (Q, NSW). All four species have large, dark-brown "shoulder spots", and it is possible that others could occur in both Tasmania and Victoria. They are separable, in part, as follows: females are virtually impossible to differentiate simply, and the most reliable characters are those of the male genitalia.
1 Male flagellar segments with scale-like hairs ........... 2

- Male flagellar segments without scale-like hairs ....... 3

2(1) Terminal process in ventral view large; median apical incision of hypandrium $\mathrm{V}$-shaped .......... ${ }^{*}$ C. tillyardi

- Terminal process in ventral view small; median apical incision of hypandrium U-shaped .......* C. orientalis

3(1) Hypandrium with median apical incision large and Vshaped .............................................. C. occidentalis - Hypandrium with median apical incision U-shaped (fig.32) ........................................... C. maculithorax

\section{Neosemidalis Enderlein}

A genus limited to the Australian region, with approximately 15 Australian species and few elsewhere. The two Tasmanian species (with few records from forested areas in the State) represent different subgenera, and specific differences in both these are largely those of male genitalia and male antennae.

$N$. (N.) nervalis Meinander (figs 35, 36) is one of a group of species with the male antennal scape distinctly broader than long and the hind wing $\mathrm{M}-\mathrm{Cu}_{1}$ crossvein striking the posterior branch of vein $M$ (rather than the stem of $M$ ). The latter feature allies it with ${ }^{*} N$. (N.) anguliceps Meinander (NSW), which has long projecting genae; genae are normal in $N$. nervalis, which is widely distributed in Australia (WA, SA, Q, NSW, V).

$N$. (L.) farinosa (Enderlein) (figs 33, 34) is allied with * $N$. (L.) acuta Meinander (Q, NSW) by having parameres without a ventral tooth, but the hypandrium of $N$. farinosa is obscure rather than being distinct and acute.

\section{Aleuropteryginae}

Two genera are recorded from Tasmania.

1 Hind wing radial crossvein meeting $\mathrm{Rs}_{\mathrm{s}}$ on $\mathrm{R}_{2+3}$; fore wing $\mathrm{R}_{4+5}$ superficially resembling anterior branch of $\mathrm{M}$; (hind wing veins $\mathrm{M}$ and $\mathrm{Cu}_{1}$ very close for more than half length of $\mathrm{Cu}_{1}$, so no clear space between them) (fig. 22) ...............(Fontenelleini) .. Cryptoscenea

- Hind wing radial crossvein meeting Rs on stem or fork; vein $M$ forked in both wings, anterior branch of fore wing vein $M$ coalescing with, or connected by crossvein to, $\mathrm{R}_{4+5}$ (fig.20) ......(Aleuropterygini) .... Heteroconis

\section{Cryptoscenea Enderlein}

A rather small genus occurring in Australia, New Zealand and New Guinea. C. australiensis (Enderlein) (figs 23-25) is the most common species and, as well as Tasmania (widely distributed), is recorded from Q, NSW, V and New Zealand (where it has been introduced). The male is very distinctive in having the parameres about twice as long as the penis (fig. 25 ). In all other described species, the parameres and penis are of similar length.

\section{Heteroconis Enderlein}

The predominant genus of Aleuropteryginae in Australia, New Guinea and the Oriental Region. The sole species recorded from Tasmania (where it seems to be rare), $H$. nigripennis Meinander (figs 26,29), is known also from WA, $Q, N S W, V$. The species are best separated on male characters and details of the position of fore wing crossveins in relation to the thickened spots on vein $M$. 


\section{Ithonidae}

A vary primitive and isolated family of Neuroptera, known from 14 species (in three genera) from Australia and a single gen us and species from western North America. "Moth lacewings" have stout furry bodies and broad wings with den se venation; their common name comes from a superficial resemblance to small hepialid motbs. They are associated particularly with sandy areas, and adults sometimes occur in very large numbers, due to mass emergences. Larvae are unlike those of any other lacewings, being scarabaeiform and subterranean. It was formerly presumed that they were predators on larvae of scarab beetles, but they are now believed to feed on exudates from plant material - a highly unusual habit for larval Neuroptera.

Only one species, thone pallida (Tillyard) (figs 37, 3941 ), is known from Tasmania (few records from the northeast) and is also widespread in NSW and V (Riek 1974). The ten species of Ithone Newman are concentrated around coastal southern Australia and have largely discrete geographical ranges. I. pallida is most similar to ${ }^{*}$ I. neopallid Riek (SA) but differs in having the mandibles straight rather than apically curved and in the gradually tapered apical sternite of the male.

About 40 species of this family are known from Australia, representing five subfamilies. Representatives of two subfamilies have been recorded from Tasmania and a third (containing a single species widespread in southeastern mainland Australia) is noted, although it seems unlikely that it would have escaped notice in the state until now. All three are southern groups and in Australia are restricted to the Bassian Province. Kempyninae and Stenosmylinae occur also in temperate South America, and the former in New Zealand. Larvae of Kempyninae are thought to be semiaquatic, as the adults (which are amongst the largest Osmylidae) often occur commonly near streams or rivers, and larvae have been found amongst low waterside vegetation. Stenosmylinae are generally more clearly terrestrial, and larvae have been found on and under bark in open forest environments. All seem to have one generation a year, with adults flying in summer.

1 Many crossveins between veins $R_{1}$ and $R_{s}$ (steely blue

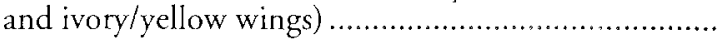

*Porisminae (* Porismus strigatus Burmeister) A single, basal, crossvein between veins $R_{1}$ and $R s$ (variously marked with brown and grey).............. 2

2(1) Fore wing vein MP forked near base of wing, usually berween separation of MA from Rs and first branch of Rs proper from stem, sometimes opposite MA/Rs separation (fig.43) .............. Kempyninae (Kempynus)

- Fore wing vein MP forked more distally, usually beyond half wing length (figs 44, 50) ............. Stenosmylinae
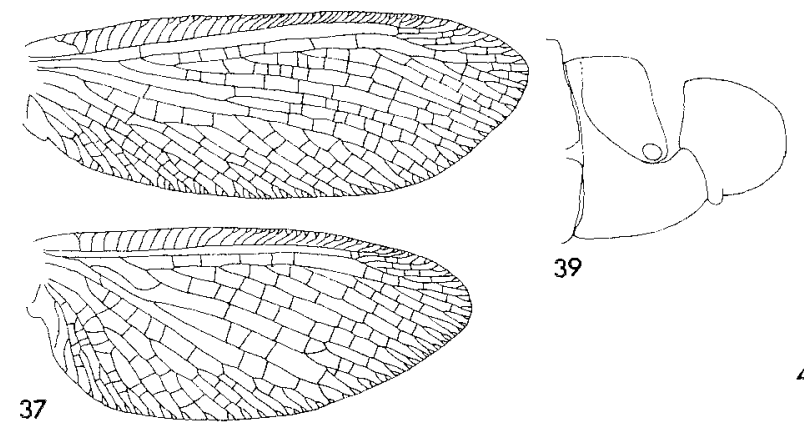

37
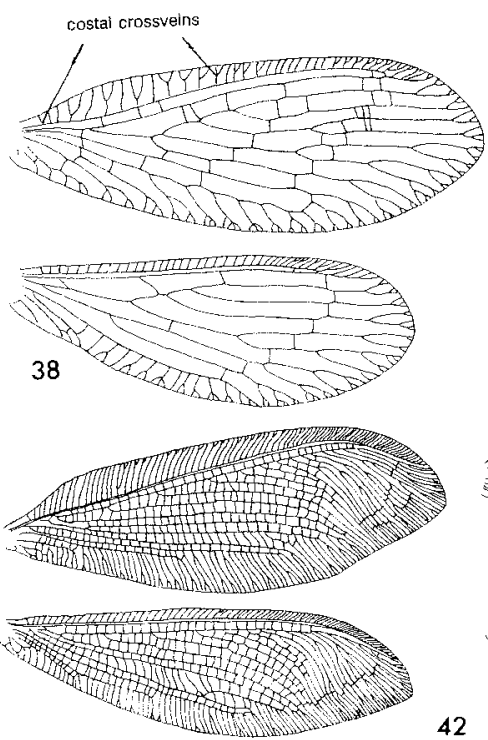

42
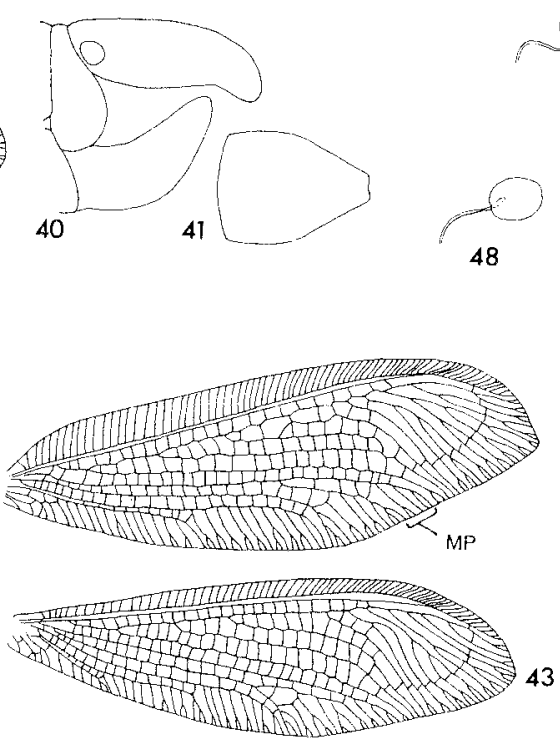

FIGS 37-43 - Fore and hind wing venation: 37, Ithone sp. (Ithonidae); 38, Austroneurorthus sp. (Neurorthidae): Ithone pallida, genitalic features; 39, fernale, apex of abdomen, lateral; 40, male, same; 41, male, last sternite, ventral. Fore and hind wings of 42, Oedosmylus rasmaniensis; 43. Kempynus longipennis (Osmylidae).
FIGS 44-50 - 44 46: Stenosmylus tenuis: 44, fore and hind wings; 45, female, apex of abdomen, lateral; 46, male, same: 47, 48 Spermatheca of 47, Kempyninae; 48, Stenosmylinae. Fore and hind wings: 49, Nymphes myrmeleonides (Nymphidae); 50, Oedosmylus latipennis (Osmylidae). 


\section{Kempyninae}

Three genera and 13 species of this group occur in Australia. Kempynus Navas is the largest genus and occurs also in New Zealand. The only Tasmanian kempynine, $K$. longipennis (Walker) (figs 51, 52), is apparently endemic to the state, where it is widely distributed, but the provenance of the type specimen (labelled only "Australia") is unknown. It seems to be most closely related to the Victorian ${ }^{*} K$. millgrovensis New, and differs by the less sinuous fore wing margin and by the female gonocoxite VII not being produced dorsally near its apex. The spermathecae of Kempynus are dumbbellshaped, in contrast to the spherical spermathecae of the other Tasmanian Osmylidae.

\section{Stenosmylinae}

Two genera are represented in Tasmania, of five known in Australia. Two others occur in South America. A third mainland genus, not uncommon in Victoria, is noted in the following key.

1 Fore wing vein MP apparently forking distally only slightly before wing margin .... 2

- Fore wing vein MP conspicuously forking around half (at most, two-thirds) length of wing (fig. 50)

Oedosmylus

2(1) Fore wing vein $2 \mathrm{~A}$ terminating opposite, or slightly beyond, origin of Rs+MA (fig. 44) .......... Stenosmylus

- Fore wing vein $2 \mathrm{~A}$ terminating opposite, or slightly basal to, separation of MA from Rs

* Stenolysmus Kimmins

Stenosmylus McLachlan

Represented by S. tenuis (Walker) (figs 44-46), a narrowwinged, brown-mottled species which can be very common; known also from WA, SA, NSW and V. In Victoria it occurs sympatrically with another common species, ${ }^{*} S$. stenopterus McLachlan, which differs in having a pronounced longitudinal dark-brown streak along the fore wing.

\section{Oedosmylus Krüger}

Oedosmylus contains eight species (New 1989b), of which two very closely related ones are found in Tasmania. Indeed, there is still some doubt as to whether they are really distinct, although some small differences seem to be relatively consistent. O. montanus Kimmins (Q, NSW) is also in this species complex.

1 Wings ovoid

O. tasmaniensis

- Wings falcate

O. latipennis

O. tasmaniensis Krüger (figs 53, 54) (also NSW, V) and O. latipennis Kimmins (figs 55, 56) (NSW, V) also overlap in range in Tasmania, although a number of localities have so far yielded only one of these two species. The accompanying figures indicate small differences in the genitalia of both sexes, though the wing shape is by far the most reliable character for most individuals seen, which can be allocated unambiguously to one or other name on this feature alone.

\section{Sisyridae}

The "sponge-flies", small, narrow-winged, brown or grey lacewings found close to fresh water. Larvae are specialised obligate "parasites" of freshwater sponges and, probably, bryozoans, and sisyrids are thus limited to areas in which these organisms occur.

The family is in need of revision and little can be done to identify the Tasmanian representatives at this stage. Sisyrids appear to be reasonably common in Tasmania, as in other parts of southeastern Australia, but there are no published records (with species names) from the state. Several species occur also in Victoria and perhaps elsewhere in the southeast. Sisyra is the predominant genus.

Sponge-flies can be confused only with Hemerobiidae and Neurorthidae, both of which differ in venational features (fig. 84). Genitalia differ markedly between these three families.

\section{${ }^{\star}$ Neurorthidae}

No records from Tasmania, but the distinctive larva (fig. 12) and the wing venation (fig. 38) of a mainland species of *Austroneurorthus Nakahara are figured here. Larvae occur in Victoria, particularly in alpine streams. The adult most resembles those of Sisyridae but is rather larger, and at least some fore wing costal crossveins are forked; they are invariably simple in Sisyridae.

Neurorthidae were formerly considered to be a subfamily of Sisyridae, but have been recognised as a distinct family for abouw 20 years. There are probably two Australian species.
51
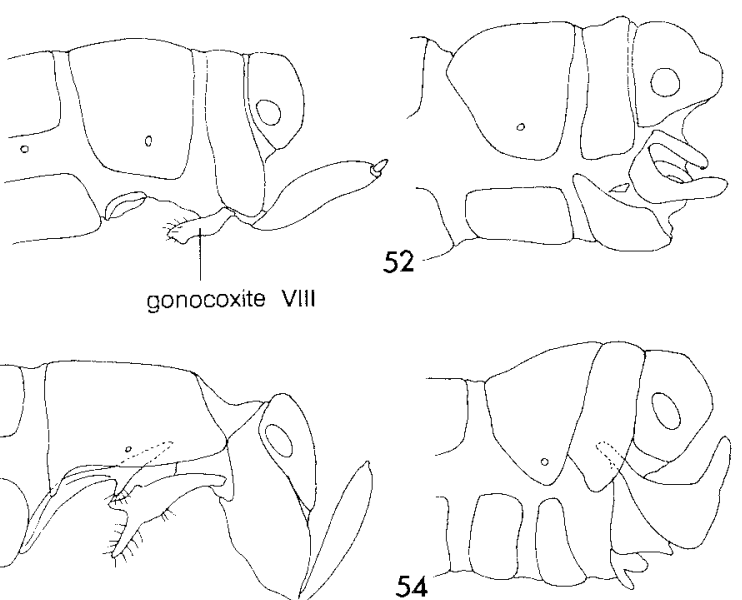

53

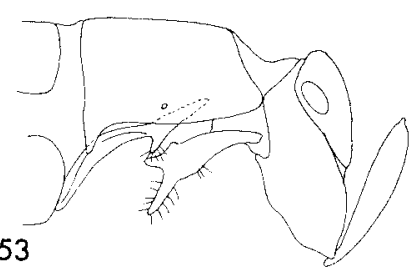

54

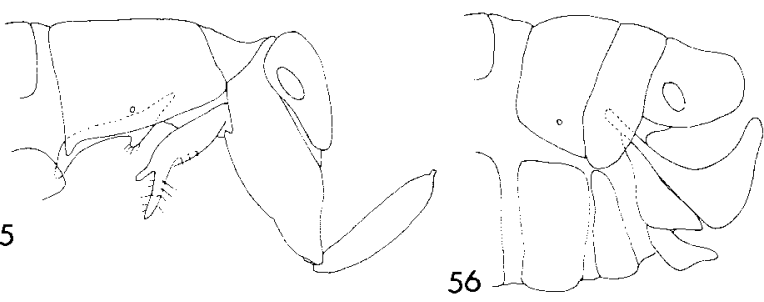

FIGS 51-56 - Osmylidae, genitalic features (51, 53, 55, female; 52, 54, 56, male), apex of abdomen, lateral: 51, 52, Kempynus longipennis; 53, 54, Oedosmylus tasmaniensis; 55, 56, O. latipennis. 


\section{Mantispidae}

Mantispids resemble small praying mantids in having enlarged raptorial fore legs, hence their common name of "mantisflies". They are completely distinctive in the Australian Neuroptera and 46 Australian species are known.

The seven Tasmanian species represent two genera, in different subfamilies, following the arrangement of Lambkin (1986a, b).

1 Anterolateral margins of mesoscutum rounded; fore tarsus with segment 1 much shorter than segments 2 5 together; two claws, each deeply divided

Calomantispa (Calomantispinae)

- Anterolateral margins of mesoscutum acutely extended; fore tarsus with segment 1 at least as long as segments 2 5 together; one claw; mid and hind claws simple......

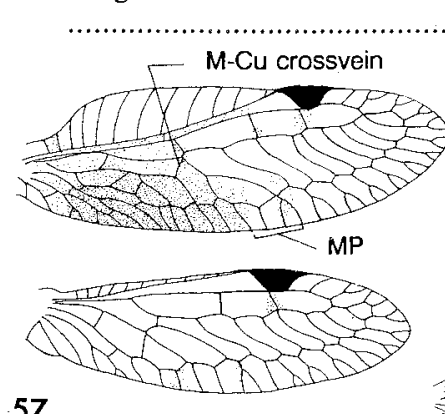
Campion (Mantispinae)
57

58
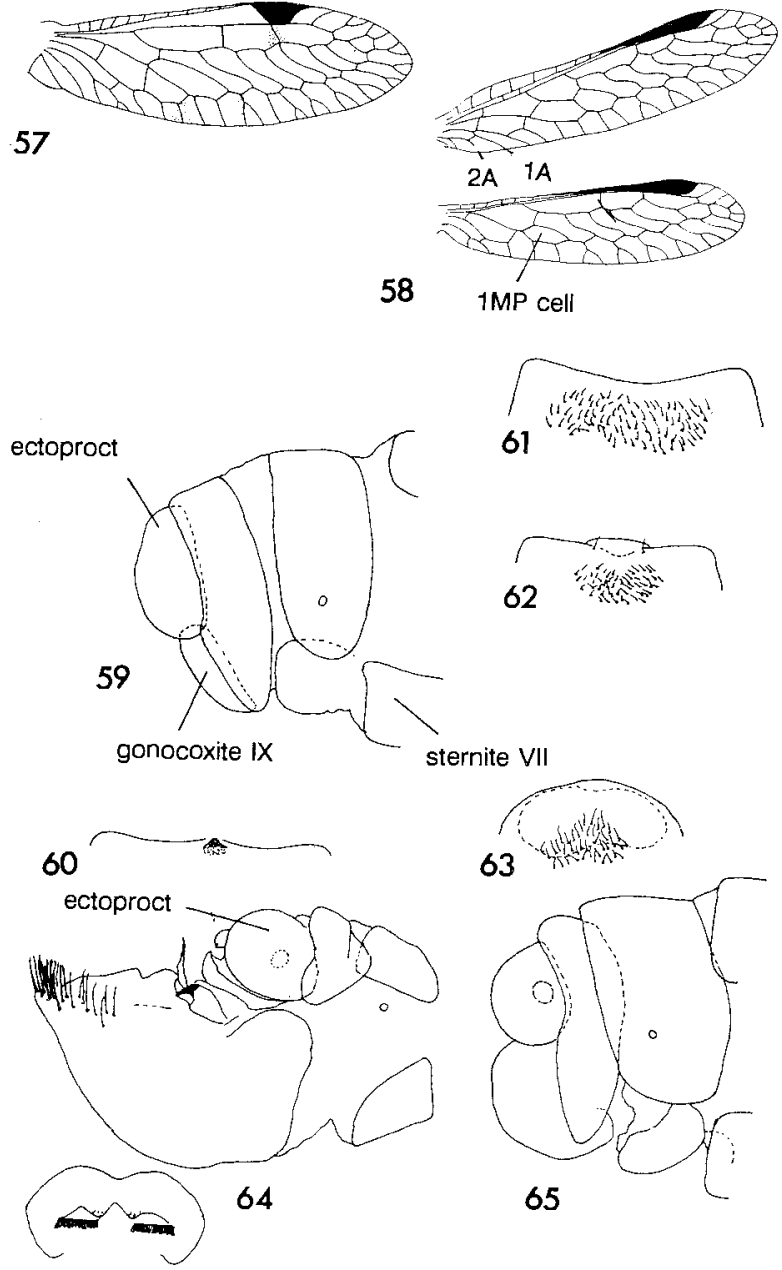

sternite VII

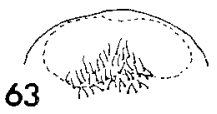

63

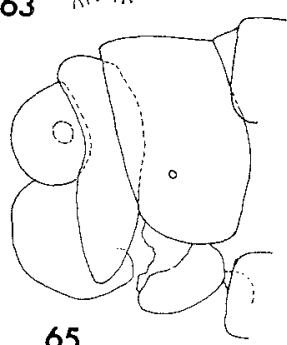

65
FIGS 57-65 - Mantispidae: fore and hind wings of 57, Calomantispa venusta; 58, Campion callosus: genitalic structures: 59, Campion sp., female, apex of abdomen, lateral; 60-63, Campion spp., female, sternite VII, ventral: 60, C. callosus; 61, C. australasiae; 62, C. impressus; 63, C. spiniferus: 64, 65, Calomantispa venusta: 64, male, apex of abdomen, lateral, with posterior view of ectoprocw ornamentation; 65, female, apex of abdomen, lateral.
The most diverse genus of Mantispidae in Australia, the endemic * Theristria Gerstaecker, has not been recorded from Tasmania, although several species occur in the southeastern mainland states. It is placed in a third subfamily, *Drepanicinae, which has a rounded mesoscutal margin and simple fore tarsal claws.

\section{Calomantipsa Banks}

The only Australian genus of Calomantispinae, a group otherwise known only from North America, is limited to eastern Australia and is distinguishable from all other Australian mantispid genera by the bifid fore tarsal claws. The three species are all brightly coloured, with the fore wings marked with bright orange. The sole Tasmanian species, C. venusta Lambkin (figs $57,64,65$ ) (also NSW, V), has two small setose anterodorsal prominences on the vertex, and fore wing vein MP forks beyond the second $\mathrm{M}-\mathrm{Cu}$ crossvein. In both the other species $\left({ }^{*}\right.$ C. spectabilis Banks, $\mathrm{Q}$; ${ }^{*}$ C. picta Stitz, NSW), the vertex lacks setose humps and fore wing vein MP forks basal to $2 \mathrm{~m}$-cu.

\section{Campion Navas}

This Australian endemic genus contains seven species, six of which are recorded from Tasmania. The other, ${ }^{*} C$. spiniferus Lambkin, is known from WA, V, NSW, SA (including Kangaroo Island) and could possibly be found in Tasmania. It is included, therefore, in the following key (from Lambkin 1986b, where many additional details are given). The species are rather similar in gross appearance and genitalic examination is sometimes necessary for unambiguous separation.

1 Fore wing jugal lobe large; hind wing with four veins leaving $1 \mathrm{MP}$ cell....

- Fore wing jugal lobe small; hind wing with three veins leaving $1 \mathrm{MP}$ cell....

2(1) Fore wing vein $\mathrm{CuA} 4$-branched (rarely 3- or 5branched); veins $1 \mathrm{~A}$ and $2 \mathrm{~A}$ each with 2 branches ..... C. rubellus

- Fore wing vein $\mathrm{CuA} 2$-branched; veins $1 \mathrm{~A}$ and $2 \mathrm{~A}$ both simple

3(2) Vertex with well-developed median ridge with fine transverse ridges on each side; pronotum 2.6-3.5 times as long as wide at maculae

C. australasiae

- Vertex smooth, with weakly defined rounded median ridge; pronotum 3.6-5.4 times as long as wide at maculae

\section{4}

4(3) Female sternite VII with broadly spaced fine posterior setae; male ectoproct with apical half of medial margin with 6-10 randomly placed short thick sessile spines; apex curved medially, acute .................. C. tenuistriga

- Female sternite VII with dense patch of thick posterior setae; male ectoproct with apical region of medial margin extended posteriorly and with three spines set on distinct pedestal; apex broad, truncate.

C. cruciferus

5(1) Female gonocoxite IX with setae concentrated along medial margin, posterior region of sternite VII simple, without strongly sclerotised area; male, medial margin of ectoproct with four spines, proximal two or three broadly spaced C. impressus

- Female gonocoxite IX with setae evenly distributed, 
posterior region of sternite VII with strongly sclerotised area; male, medial margin of ectoproct with patch of six closely approximated apical spines ....

6(5) Female sternite VII with strongly sclerotised area on posterior margin; male with spines along medial margin of ectoproct very slightly pedestalled .......... C. callosus

- Female sternite VII with posterior and posterolateral regions strongly sclerotised, rugose; male with spines along medial region of ectoproct at most only slightly pedestalled ${ }^{*}$ C. spiniferus

C. rubellus Navas (fig. 69) is very widely distributed around the southern half of Australia and is known also from NT. In general, its distribution coincides strongly with that of $C$. australasiae (Guerin) (figs $61,66,72$ ), although the latter is known from Flinders Is. and the Furneaux group, as well as "Tasmania proper". C. tenuistriga (Gerstaecker) (fig. 75), apparently the most common species of Campion, occurs throughout Australia but has only recently been recorded from Tasmania (Lambkin 1987). C. cruciferus (Navas) (figs 70, 74) (NSW, V) is a rarer species, apparently restricted to the southeast of Australia. C. callosus Lambkin (figs $58,60,68,73$ ) is predominantly eastern, with a few specimens known from WA. C. impressus (Navas) (figs 62, 67) is widely distributed in eastern Australia.

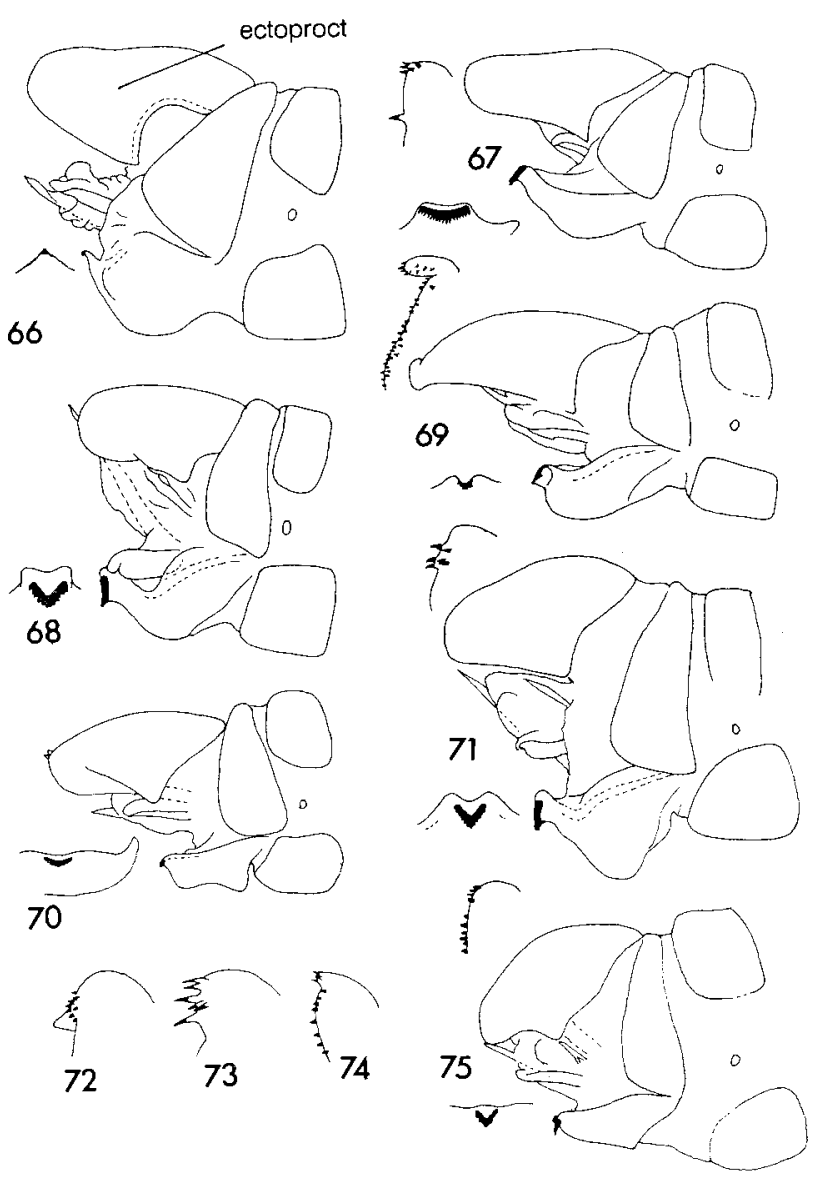

FIGS 66-75 - Campion spp., males, apex of abdomen, lateral, with posterior view of last sternite ornamentation and dorsal view of inner margin of ectoproct: $66,72, \mathrm{C}$. australasiae; 67, C. impressus; 68, 73, C. callosus; 69, C. rubellus; 70,74, C. cruciferus; 71 , C. spiniferus; 75 , C. tenuistriga.

\section{Hemerobiidae}

Small, generally brown lace wings, always with at least two Rs veins arising directly from vein $\mathrm{R}$, often with three-five such veins; wings sometimes falcate. Larvae are active campodeiform predators and never carry debris (cf. Chrysopidae). They occur on vegetation, predominantly trees and shrubs. There are 35 Australian species, nearly all endemic. The seven Tasmanian species all represent different genera, two being here formally recorded from the state for the first time. The most diverse Australian genus, ${ }^{*}$ Carobius Banks, has now been found in Tasmania but is included in the following key. Subfamily divisions are not recognised in Hemerobiidae.

1 Fore wing without recurrent humeral vein .............. 2

Fore wing with recurrent humeral vein .................. 4

2(1) Fore wing veins $S_{c}$ and $R$ widely spaced, linked by several crossveins; wings broad and bluntly rounded (fig 82). Psectra

- Fore wing veins $S c$ and $\mathrm{R}$ close together throughout their lengths, with basal crossvein only; wings rather narrow.

3(2) Fore wing with three-five Rs veins (fig. 76)

- Fore wing with two Rs veins, a crossvein from $\mathrm{R}$ to anterior fork of basal $\mathrm{Rs}$ vein (fig. 83) ...... Zachobiella

4(1) Fore wing tapered to narrow apex, usually falcate .... 5 Fore wing not strongly tapered or falcate ...............6

5(4) Fore wing relatively broad, with two series of gradate veins(fig. 77 ) Drepanacra

- Fore wing relatively narrow, with three series of gradate veins (fig. 80) Megalomina

6(4) Fore wing without crossvein from vein $R$ to basal branch of Rs (fig. 81) ........................... Psychobiella

- Fore wing with crossvein from vein $\mathrm{R}$ to basal branch of Rs.

7(6) Basal branch of vein Rs forked near base; a crossvein from $R$ to distal branch of Rs (fig. 78) .... Notherobius

- Basal branch of vein Rs now forked near base; no crossvein from $\mathrm{R}$ to distal branch of Rs (fig. 79) ........

* Carobius

\section{Micromus Rambur}

This large cosmopolitan genus is represented by $M$. tasmaniae (Walker) (figs 85, 86), by far the most abundant and widely distributed Australian hemerobiid. It usually comprises around 90-95\% of "random" collections of Hemerobiidae in Australia and is superficially recognisable by its long narrow wings. The northern ${ }^{*} M$. timidus Hagen is generally larger and the ectoproct of both sexes has an elongate ventral process. In $M$. tasmaniae the female ectoproct is simple and that of the male has only a short blunt process. $M$. tasmaniae has been captured commonly throughout Tasmania.

\section{Zachobiella Banks}

This small Australian/Oriental genus contains three species in Australia. The most common of these and the only 
Tasmanian species, $Z$. submarginata Esben-Petersen (figs 93, $94)$, seems to be generally rare, though widely distributed through castern $Q, N S W$ and $V$. It closely resembles ${ }^{*} Z$. lobata New (WA), but genitalia of both sexes are distinctive.

\section{Psectra Hagen}

Five species of this widely distributed genus are known from Australia, of which P. nakaharai New (figs 95, 96) occurs in Tasmania (also NSW). P. nakaharailacks the dark fore wing band of*P. obliqua (Banks) (Q, NSW) and is most similar to ${ }^{*} P$. tillyardi (Kimmins) (Q, NSW) in having the fore wings very finely mottled with pale grey to greyish brown, rather than with more discrete patches of shading. These two species differ markedly on features of the abdominal apex: (1) in $P$. nakaharai the median process from male tergite VIII is much shorter than in * P. tillyardi; (2) the female sternite VII of $P$. nakaharai is medially excavated, unlike ${ }^{*} P$. tillyardi. They appear to be closely related.

\section{Drepanacra Tillyard}

Now contains only $D$. binocula (Newman) (figs 87,88 ), a falcate-winged species which is individually very variable in details of wing pattern and coloration. Historically many of the "varieties" have been treated as distinct taxa, with many names applied - including the variety tasmanica Tillyard to a dark-winged Tasmanian form. These variations were all recognised as conspecific by Tillyard (1923). D. binocula is common and widely distributed throughout Australia (except NT) and New Zealand, but appears to be most abundant in woodlands and forests in the southeast. Some individuals superficially resemble examples of the following taxon, but differ in the number of gradate series.

\section{Megalomina Banks}

Another Australian endemic genus, containing three superficially rather different species which were placed in separate genera until recently (New 1988). M. berothoides (McLachlan) (figs 91, 92) differs from the other two in having clearly falcate fore wings, and occurs sporadically throughout southeastern Australia. Ihave seen few Tasmanian examples.

\section{Psychobiella Banks}

Psychobiella, also confined to the Australian region, contains two species of rather large dark Hemerobiidae with rounded wings. P. sordida (Banks) (also known as $P$. fusca Tillyard synonymised by New 1988) (figs 89,90 ) differs from ${ }^{*} P$. occidentalis New (SA, WA) in features of male terminalia, though the females are virtually identical in appearance. In $P$. sordida (known from Q, NSW, $\mathrm{V}$ as well as Tasmania), the male ectoproct is tapered ventrally rather than hooked, and the parameres have a strong ventral hook. It seems to be rather rare, but has been captured in small numbers in woodland environments and at light.

\section{Notherobius New}

This genus has been differentiated only recently from * Carobius Banks by New (1988), although the wing venations of the two genera are distinctive. The three species are all known only from the southeast, and the single Tasmanian
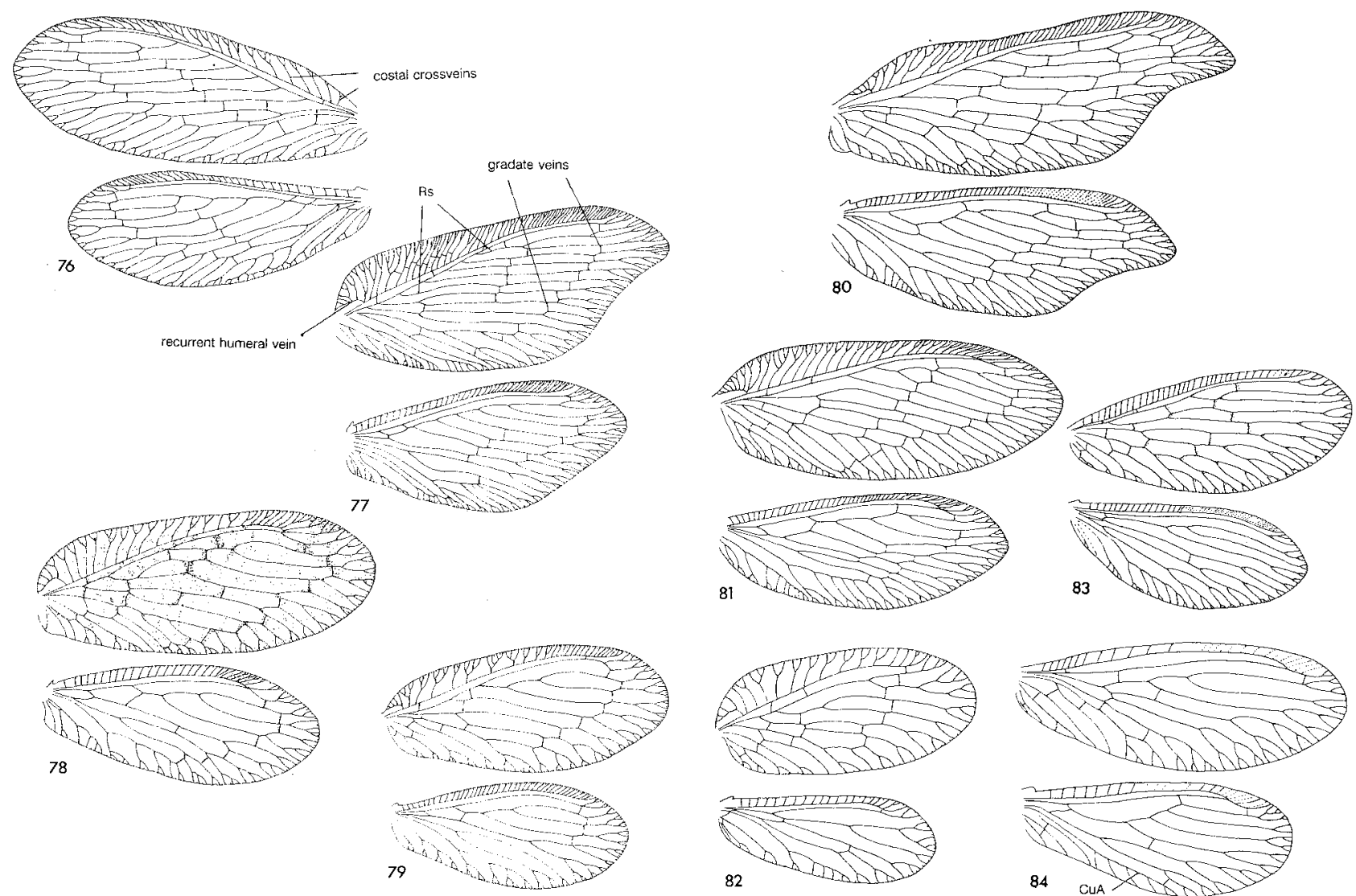

FIGS 76-84 - Hemerobiidae, fore and bind wings: 76, Micromus tasmaniae; 77, Drepanacra binocula; 78, Notherobius nothofagi; 79, Carobius sp.; 80, Megalomima berothoides; 81, Psychobiella sordida; 82, Psectra nakaharai; 83, Zachobiella submarginata; 84 , (Sisyridae) Sisyra sp. 
representative, $N$. nothofagi $\mathrm{New}$ (figs 97, 98), is separable from the others by the crossvein from the basal branch of fore wing vein Rs meeting the base of rhe distal branch of $R$, rather than $\mathrm{R}$ before the origin of the distal branch. It is known also from Victoria and has been taken predominantly in upland wet forest environments, including Nothofagus.

\section{Chrysopidae}

The "green lacewings" or "golden eyes", are a cosmopolitan family (except for New Zealand), with nearly 2000 species recognised worldwide. Slightly more than 50 are known from Australia, of which seven (? eight) occur in Tasmania. Two species of the primitive subfamily Nothochrysinae are included, one being a Tasmanian endemic.

1 Fore wing with jugal lobe present; vein Psm merges with inner gradate series; vein Psc merges with outer gradate series (fig. 99) (Nothochrysinae) ...... Dictyochrysa

- Fore wing with jugal lobe reduced or absent; vein Psm relatively straight, merges with outer gradate series (fig. 101) (Chrysopinae) 2

2(1) Fore wing costal cell broadened abruptly at base (fig. 100).

- Fore wing costal cell narrow at base (fig. 101) ..........
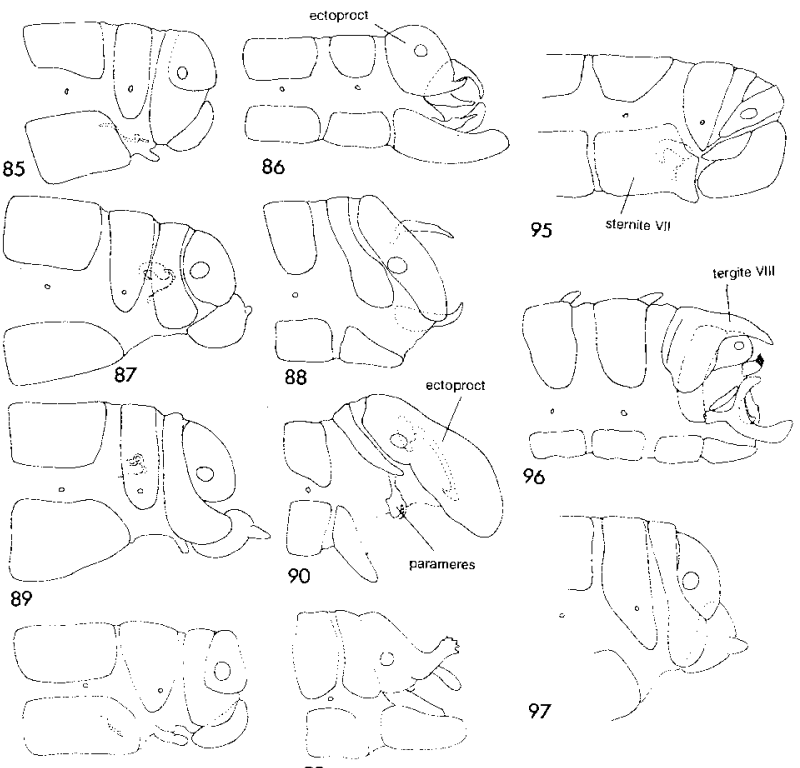

91
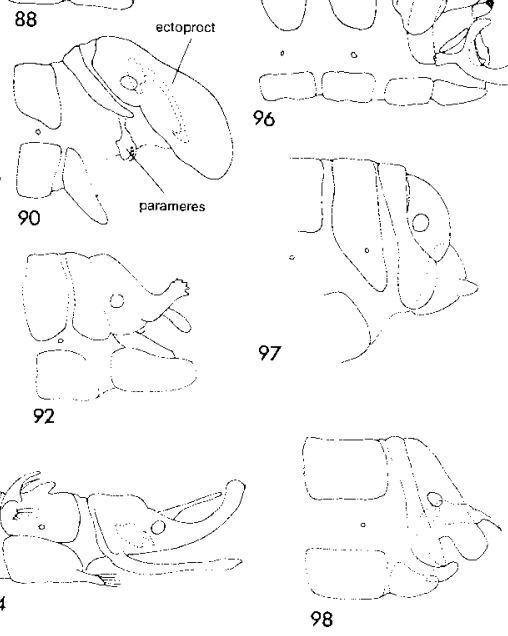

93

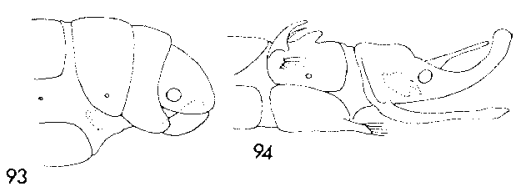

FIGS 85-98 - Hemerobiidae, genitalic features $(85,87$, 89, 91, 93, 95, 97, female; 86, 88,90, 92, 94, 96, 98 male), apex of abdomen, lateral: 85,86 , Micromus tasmaniae; 87 , 88, Drepanacra binocula; 89, 90, Psychobiella sordida; 91 , 92, Megalomima berothoides; 93, 94, Zachobiella submarginata; 95, 96, Psectra nakaharai; 97, 98, Notherobius nothofagi.
3(2) Fore wing im cell subtriangular.... (Ankylopteryx) Fore wing im cell subquadrangular. Nothancyla

4(2) Fore wing im cell subtriangular (smaller, relatively delicate species) (fig. 101) ..... Chrysopas.l. (Species were allocated to Apertochrysa Tjeder and Mallada Navas by Brooks \& Bernard 1991).

- Forewing im cell subquadrangular (fig. 102) (larger, robust species) Italochrysa

\section{Nothochrysinae}

Dictyochrysa Esben-Petersen

Differs from the other endemic Australian nothochrysine genus, ${ }^{*}$ Triplochrysa Kimmins, by having at least five irregular series of gradate veins, rather than three defined serics. The three species are all Bassian.

1 Thorax with ivory midline, darkened along sides to give broad brown lateral stripes (fig. 109) ....... D. latifascia

- Thorax not as above: if pale near midline, lateral borders not strongly darkened.

2(1) Pterothorax pale brown (face usually patterned; pronotum with strongly contrasted pattern: fig. 110)

D. peterseni

- Pterostigma very dark brown (face not patterned; pronotum predominantly dark brown, traces of pattern) * D. fulva

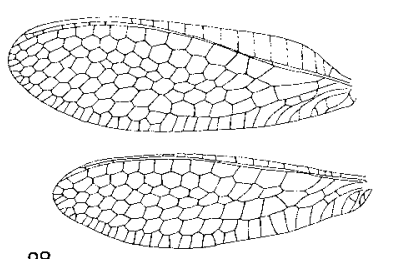

99
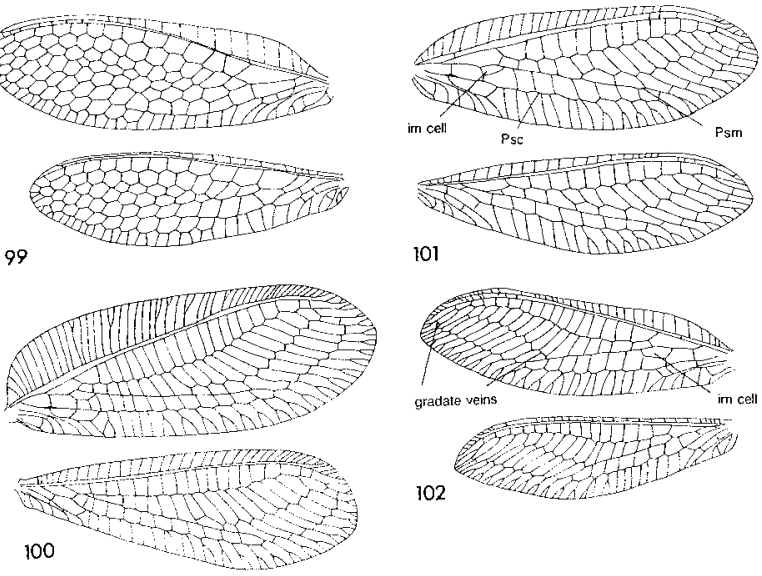

100
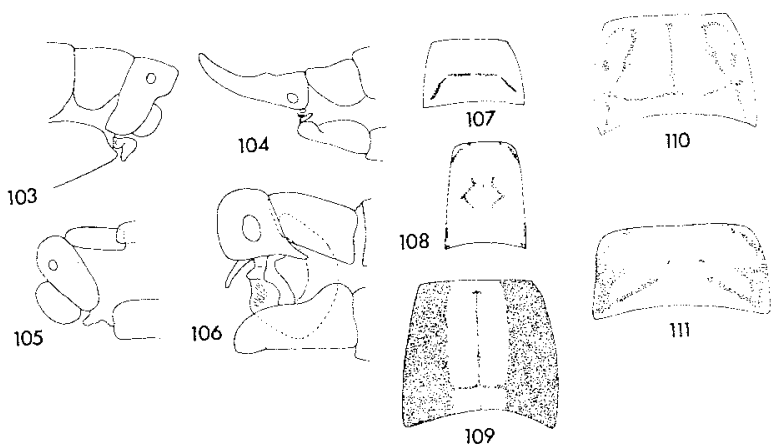

111

FIGS 99-111 - Chrysopidae, fore and hind wings: 99, Dictyochrysa sp; 100, Nothancyla verreauxi; 101, Chrysopa sp.; 102, Italochrysa sp.; 103, female, apex of abdomen, lateral of $\mathrm{N}$. verreauxi; 104, same, male; 105, same, female of Ankylopteryx pallida; 106, same, male; pronotal patterns: 107, C. ramburi; 108, C. edwardsi; 109, D. latifascia; 110, D. peterseni; 111, I. insignis. 
D. latifascia Kimmins is known only from Tasmania. $D$. peterseni Kimmins is the most widespread species in the genus (WA, SA, Q, NSW, V as well as Tasmania) and some datk individuals may be difficult to separate from ${ }^{*} D$. fulva Esben-Petersen (Q, NSW, V).

\section{Chrysopinae}

\section{(*) Ankylopteryx Brauer}

A predominantly tropical genus. Its incidence in Tasmania is anomalous and needs verification, as it is not otherwise known from the southern half of Australia. A. immaculata Brauer has not been recorded since it was described in 1864 , and it is possible that it is conspecific with the taxon now known as Nothancyla verreauxi Navas, which differs in wing venation mainly on the form of the im cell.

\section{Nothancyla Navas}

A monobasic genus with a single Bassian species (N. verreauxi - figs 103, 104) which apparently does not extend to Q. It is unusual in lacking the basal subcostal crossvein and in the greatly elongated ectoproct and tergite IX of the male. Found in forested environments.

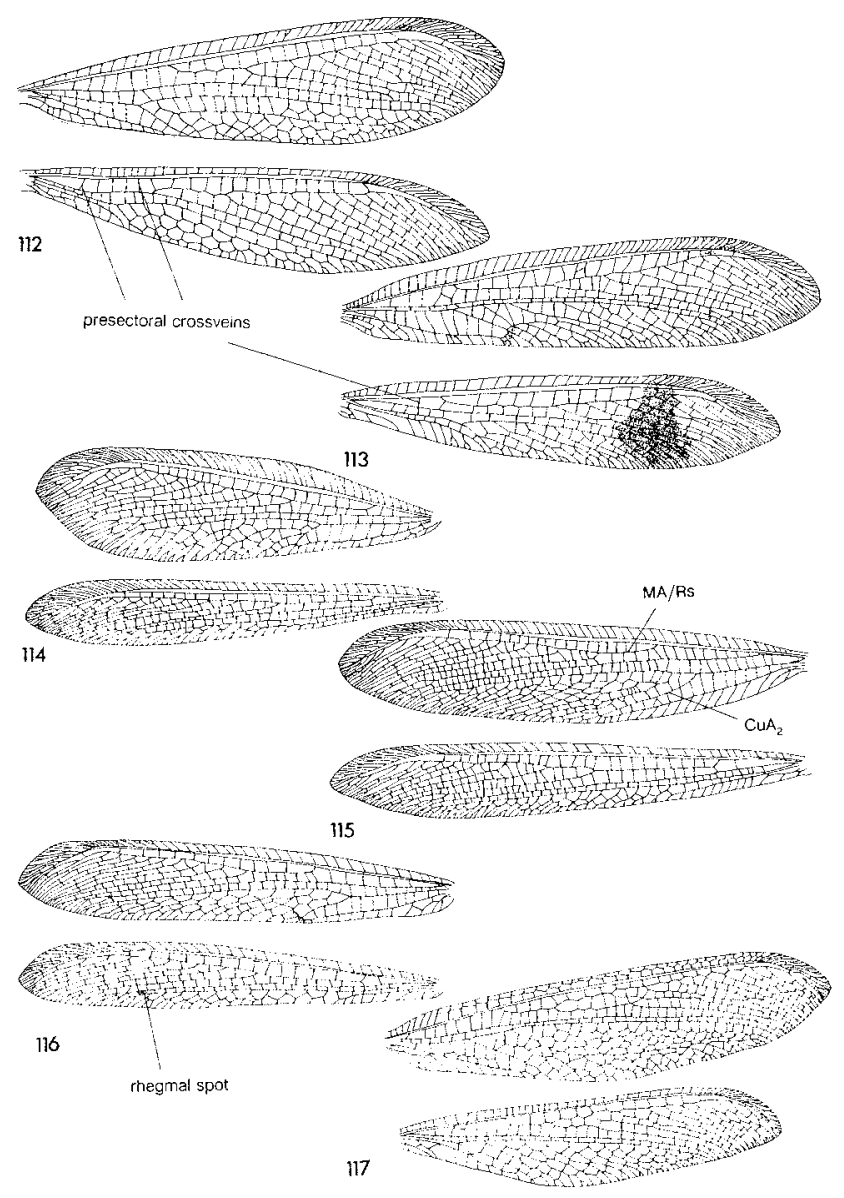

FIGS 112-117 - Myrmeleontidae, fore and bind wings: 112, Myrmeleon acer; 113, Glenoleon falsus; 114, Mossega indecisa; 115, Escura australis; 116, Bandidus vafer; 117, Heoclisis fundata.

\section{Italochrysa Principi}

A widely distributed genus containing nine Australian species, which are almost all endemic. I. insignis (Walker) (figs 102, 111) is by far the most common of these, occurring throughout the country. The pronotal pattern (with the opposed " $E$ " marks) is distinctive, although it is somewhat variable in intensity. I. insignis is the largest and most "robust" Tasmanian chrysopid.

\section{"Chrysopa Leach s.l."}

This is regarded as a "holding genus" to which a vast array of species has been uncritically referred, and its use here follows New (1980). This has now been outdated by the thorough generic revision of Chrysopidae by Brooks \& Barnard (1990) but, as generic separations rely on genitalic features to a large extent, the key does not include these. Three species are known from Tasmania (of 25 currently included in this complex in Australia), and a fourth, one of the most common species throughout mainland Australia, is included in the following key.

1 An elongate black interantennal spot and 2 pronounced black vertex patches; prothorax unmarked

Mallada tripunctata

- Vertex unmarked, or pronotum with black markings behind anterior region .......................................... 2

2(1) Dorsum of prothorax not patterned with black; usually with small lateral black mark beneath anterolateral margin (with or without dark genal spot: if this is present, vertex may also be darkened) ............ Mallada signata

- Dorsum of thorax with discrete black streaks clearly visible from dorsal surface ...3

3(2) Pronotum with laterally opposed sinuous "V" marks each side of midline (fig. 108) ... Apertochrysa edwardsi Pronotum with central transverse streak each side of midline (fig. 107) * Plesiochrysa ramburi

M. signata (Schneider) is the most common species of Chrysopidae in Australia, though relatively few examples from Tasmania have been seen. It is rather variable in body markings, especially those on the vertex, and some specimens are almost as heavily marked as $M$. tripunctata (McLachlan). $M$. signata normally has a well-defined medial stripe along the scape, in addition to the external streak of both these species. The two species appear to be very closely related. $M$. tripunctata is also widespread on the Australian mainland, but is not as abundant as $M$. signata.

A. edwardsi (Banks) is a widespread Bassian species, and appears to be the most abundant chrysopid in Tasmania. It is related to *A. punctithorax (New) (ACT) in general form but differs in details of body markings.

* $P$. ramburi (Schneider), a very common species elsewhere in Australia, may well occur in Tasmania. The pronotal markings are diagnostic.

\section{*Psychopsidae}

One species of * Psychopsis Newman, * $P$. mimica Newman, occurs widely across sourhern Australia, but is rare in Victoria. It is unlikely that it would have been overlooked in Tasmania, but it is noted here for reference. Comparative details are given by New (1989a). 


\section{Nymphidae}

This family is restricted to Australia and the New Guinea region and is divisible into two discrete groups of genera, formerly separated at the family level as Myiodactylidae and Nymphidae. The former have broader wings and lack tibial spurs, whereas the latter (generally larger) have relatively elongate wings and short tibial spurs. Larvae of the former group are circular, flattened, "ambushing" arboreal insects, whereas known representatives of the latter are active ground and litter dwellers with the form shown in figure 16. No broad-winged forms, which are presumed to be the more primitive members of this archaic family, have been recorded from Tasmania. The sole recorded species in Tasmania, Nymphes myrmeleonides Leach (figs 136, 137), is amongst the largest Tasmanian lacewings (FW 28-42 mm), and tawny brown and black, with the apical region of the wings having a conspicuous white mark. It is widely distributed in eastern Australia. The body coloration and white wing mark allies $N$. myrmeleonides with ${ }^{*} N$. paramyrmeleonides New (Q). The latter has the fore wing CuA fork beyond the separation of vein MA from Rs, whereas the fork is clearly basal to the separation in $N$. myrmeleonides.

\section{Myrmeleontidae}

The "antlions" are the largest family of Neuroptera. About 2000 species are known, with more than 210 from Australia - nearly all of them endemic.

Higher classification of Myrmeleontidae has been based almost entirely on adult features, particularly those of wing venation, and the precise status of groups variously allocated as subfamilies or tribes is sometimes debatable. Three major groups occur in Australia: ${ }^{*}$ Stilbopteryginae are an endemic group absent from Tasmania, but representatives of both Myrmeleontinae (tribes Myrmeleontini, Dendroleontini, Distoleontini) and Acanthaclisinae occur there.

The following key, based on New (1985a) separates these groups.

1 Vein $1 \mathrm{~A}$ in hind wing with five or more branches; antennae short, strongly clubbed (very large species). *Stilbopteryginae

- Vein 1A in hind wing never with more than three or four branches; antennae, if short, not strongly clubbed or species smaller

....2

2(1) Femoral sense hair now present on hind leg (usually now densely hairy; one-six presectoral crossveins in hind wing, if more than two, fore wing costal cells simple except (rarely) immediately before pterostigma; legs usually slender, spurs and claws various) (Myrmeleontinae) ...3

- Femoral sense hair present on hind leg (large, densely hairy; more than four presectoral crossveins in hind wing; fore wing costal cells partially or wholly biareolate [fig. 117]; legs short and stout, spurs and tarsal claws very strongly arched) Acanthaclisinae

3(2) Fore wing vein $2 \mathrm{~A}$ clearly separable from $1 \mathrm{~A}$ at base; $2 \mathrm{~A}$ and $3 \mathrm{~A}$ linked by crossvein or meeting at a point (figs $113,114)$
- Fore wing vein $2 \mathrm{~A}$ close to $1 \mathrm{~A}$ at base; $2 \mathrm{~A}$ and $3 \mathrm{~A}$ closely associated along central length

... 4

4(3) Hind wing vein Rs arising opposite or beyond medial fork; usually four or more hind wing presectoral crossveins (fig. 112)......................... Myrmeleontini

- Hind wing vein Rs arising well before medial fork; one (rarely two or more) hind wing presectoral crossveins

5(4) Forewing veins $\mathrm{CuA}_{2}$ and $(\mathrm{CuP}+1 \mathrm{~A})$ elongated, parallel to $\mathrm{CuA}_{1}$ and hind margin of wing for considerable length (fore wing costal cells sometimes partially biareolate) ...................................... * Protoplectrini Fore wing veins $\mathrm{CuA}_{2}$ and $(\mathrm{CuP}+1 \mathrm{~A})$ not as above, short (fore wing costal cells simple) ........ Distoleontini

\section{Myrmeleontinae}

The predominant subfamily in Australia, with 185 species at present described.

Myrmeleontini is represented in Tasmania by a "typical antlion" of the genus Myrmeleon L., $M$. acer Walker (figs $118,120)$, which is common and widespread throughout Australia and may extend elsewhere in the western Pacific region. Myrmeleon is one of three genera of the tribe in Australia and contains 20 described Australian species. $M$. acerbelongs to a group of dark-bodied species with unmarked wings, pronotum without a median stripe and frons largely
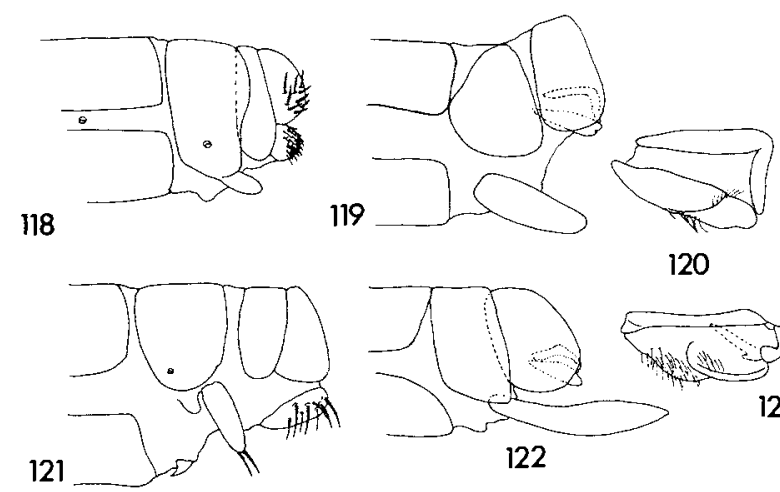

120
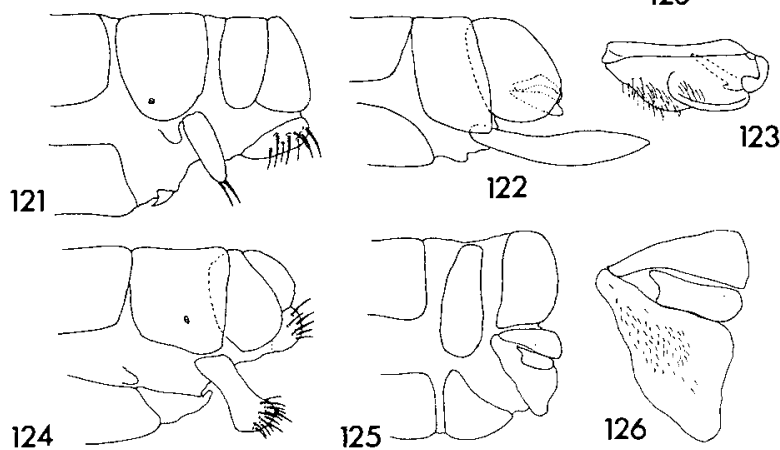

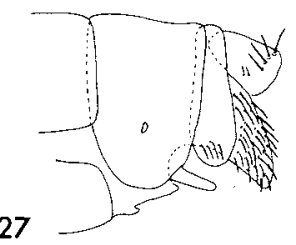

125
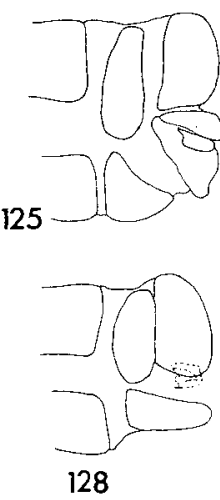

126
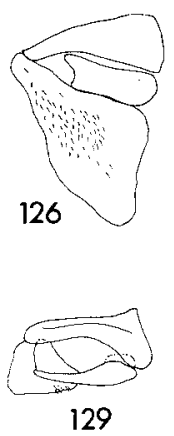

FIGS 118-129 - Myrmeleontidae, genitalic structures $(118,121,124,127$, female, remainder male); each trio of figures is female, apex of abdomen, lateral; male, apex of abdomen, lateral; male, genitalic complex, lateral: 118-120, Myrmeleon acer; 121-123, Mossega indecisa; 124-126, Glenoleon falsus; 127-129, Escura australis. 
black. It most resembles * $M$. regularis (Esben-Petersen), but has a slightly more complex fore wing venation and the posterior of the clypeus is usually blackened, rather than pale.

Dendroleontini is the largest antlion tribe in Australia (New 1985b). Single species of two genera occur in Tasmania. These genera are separable on numerous features and are distinguished by the following key, in which the very diverse mainland genus *Austrogymnocnemia EsbenPetersen is also included.

1 Tibial spurs absent *Austrogymnocnemia

- Tibial spurs present

2(1) Tarsal claws opposable on last tarsal segment ............

- Tarsal claws not opposable on last tarsal segment ...... Glenoleon

Glenoleon Banks

A complex of 31 Australian species, which may eventually need generic subdivision. The single Tasmanian species, G. falsus (Walker) (figs 124-126), is widespread on the mainland and belongs to a group of relatively large species (FW around $25 \mathrm{~mm}$ or more) with a conspicuous black hind wing band. The fore wing is rather narrow, in contrast to
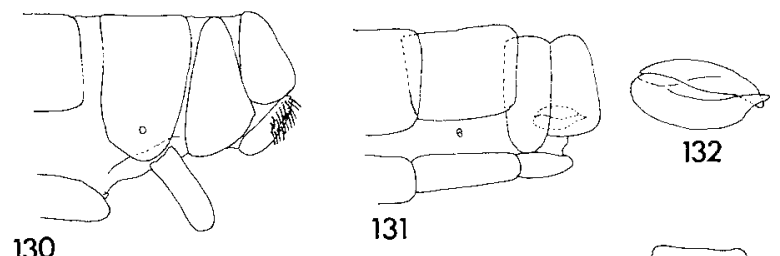

130

131

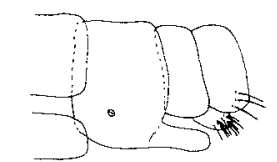

133

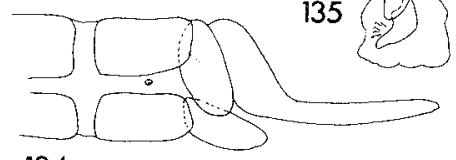

134
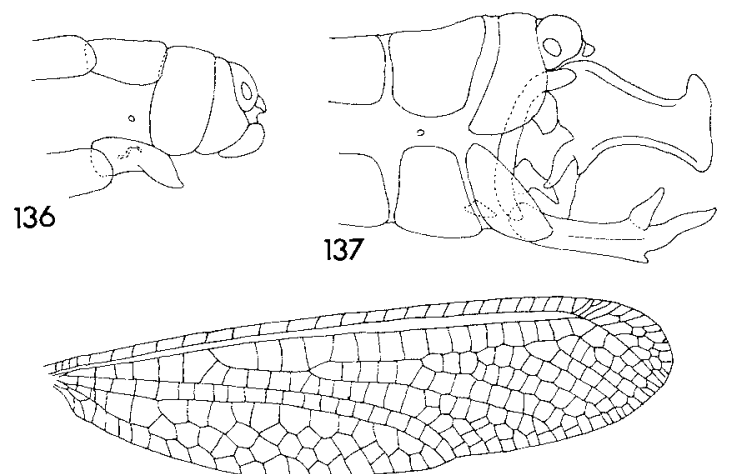

138

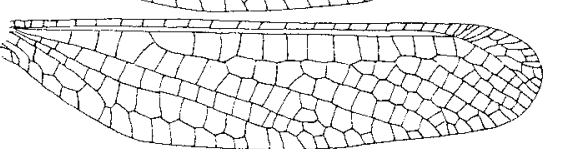

FIGS 130-138 - Myrmeleontidae, Nymphidae, Ascalaphidae. 130-135, Myrmeleontidae, notation as figures 118-129. 130-132, Bandidus vafer; 133-135, Heoclisis fundata; 136, 137, Nymphidae: Nymphes myrmeleonides: apex of abdomen, lateral: 136, female; 137, male; 138, Suhpalacsa sp.: Ascalaphidae fore and hind wings. other banded hind wing species such as the northern ${ }^{*} G$. conspersum Banks, and more resembles that of* $G$. secula New (NT, WA). *G. pulchellus (Rambur), with two black bands across the hind wing, occurs throughout eastern Australia, including southern Victoria, and could possibly occur in Tasmania.

\section{Mossega Navas}

A genus of four species, three of which are northern. Mossega indecisa Banks (figs 121-123) is very variable, and the name may be applied currently to a group of sibling species. The hind wing is both longer and narrower than the fore wing and the fore wing costal crossveins may be largely or irregularly biareolate. It occurs in many parts of Australia.

Distoleontini are also well represented in Australia (New 1985 c). Only two species, in different genera, occur in Tasmania but, as the most abundant distoleontine in Australia ( ${ }^{*}$ Distoleon bistrigatus (Rambur)) occurs on Mornington Peninsula in Victoria and in southern SA, ${ }^{*}$ Distoleon is also included in the following key.

1 Fore wing vein $\mathrm{CuA}$ long, reaching hind margin of wing opposite, or beyond, separation of MA from Rs (fig. 115) Escura

- Fore wing vein $\mathrm{CuA}$ shorter, reaching hind margin of wing well before separation of MA from Rs ............ 2

2(1) Tibial spurs extending to about apex of $t_{2}$, always beyond apex of $t_{1}$ (if longer - non-Tasmanian species - male parameres now elaborated or hooked, and species generally slender Bandidus

- Tibial spurs very long, extending to or beyond apex of $\mathrm{t}_{4}$ (male parameres fused and strongly hooked, sturdy species)

*Distoleon

* Distoleon Banks contains three, possibly four Australian species.

${ }^{*} D$. bistrigatus is large (FW $35-40 \mathrm{~mm}$ ), and the pointed hind wing has an oblique preapical black or dark-brown streak. Other species are considerably smaller.

\section{Escura Navas}

Nine Australian species, of which E. australis(Esben-Petersen) (figs 127-129) is one of the largest (FW $30-36 \mathrm{~mm}$ ) and is known also from NSW and V. It lacks conspicuous fore wing streaks, but has many distal gradate veins shaded. It thus resembles $\left(^{*}\right)$ E. divergens Navas (known only from the type: "Australia") but differs from it in having the central abdominal tergites with conspicuous ivory or yellow markings rather than just the posterior rim pale.

\section{Bandidus Navas}

A large complex of rather varied species, with 36 species described in Australia. The single species known from Tasmania, B. vafer (Walker) (figs 130-132), appears to be confined to the eastern Bassian province and is usually rather larger (FW 24-34 mm) than many of its congenors. The fore wing markings are diffuse, with only the distal radial gradate crossveins shaded and no distinct preapical fore wing streak or cubital mark. The frons does not have dense white hairs (as does ${ }^{*} B$. canifrons Navas: SA, Q, NSW, V, which also usually has a large fore wing cubital spot). The hind wing has a distinct rhegmal spot (unlike* B. nigrifronsNavas: "Australie") and $B$. vafer differs from ${ }^{*} B$. cornutus $\mathrm{New}(\mathrm{V})$ in having the central abdominal tergites black with a narrow, yellow 
posterior border rather than with yellow spots each side of the midline.

\section{Acanthaclisinae}

Four genera, with 16 described species, occur in Australia (New 1985c). The single Tasmanian representative belongs to the largest of these, separable from ${ }^{*}$ Cosina Navas by having many fewer hind wing presectoral crossveins (5-8 cf. $11-20$ ) and hind wing Rs arising about one-quarter wing length rather than more distally.

\section{Heoclisis Navas}

Heoclisis fundata (Walker) (figs 133-135) is very widely distributed in Australia and it is rather variable. It has a pronounced median dorsal black pronotal stripe and is a large species (FW 40-50), commonly found in sandy areas. In Heoclisis the fore wing costal crossveins are linked along the prestigmal length of the costal cell.

\section{${ }^{*}$ Ascalaphidae}

Not known from Tasmania. All Australian Ascalaphidae (36 described species) belong to the subfamily Ascalaphinae, in which the large eyes are divided horizontally by a welldefined sulcus (New 1984). Only four species are known from Victoria, none being common there, and it is rather unlikely that they will be found in Tasmania.

\section{ACKNOWLEDGEMENTS}

Mr Evan Schmidt kindly collected a large number of Tasmanian lacewings during his recent work on Tasmanian Psocoptera. I am also grateful to the curators of major insect collections in Australia for allowing me to utilise records from Neuroptera in their care. Dr C.N. Smithers kindly commented on a draft of this account.

\section{REFERENCES}

Brooks, S.J. \& Barnard, P.C., 1990: The green lacewings of the world: a generic review (Neuroptera: Chrysopidae). Bull. Br. Mus. nat. Hist. (Ent.) 59: 117-286.

Canari), M., Semeria, Y. \& New, T.R. (Eds), 1984: BiologyoF CHRYSOPIDAE. W. Junk, Dordrecht.
LAMBKIN, K.L., 1986a: A revision of the Australian Mantispidae (Insecta: Neuroptera) with a contribution to the classification of the family. I. General and Drepanicinae. Aust. J. Zool. Suppl. 116: 1-142.

Lambin, K.L., 1986b: A revision of the Australian Mantispidae (Insecta: Neuroptera) with a contribution to the classification of the family. II. Calomantispinae and Mantispinae. Aust. J. Zool. Suppl. 117: 1-113.

LambKIN, K.L., 1986c: The Australian Mantispidae (Neuroptera): supplementary notes. Gen. appl. Ent. 19: 11-14.

Meinander, M., 1972: A revision of the family Coniopterygidae (Planipennia). Ann. zool. Fennica 136: 1-357.

Meinander, M., 1990 The Coniopterygidae (Neuroptera, Planipennia). A check-list of the species of the world, descriptions of new species and other new data. Acta zool. Fennica 189: 1-95.

NEw, T.R., 1980: A revision of the Australian Chrysopidae (Insecta: Neuroptera). Aust. J. Zool. Suppl. 77: 1-143.

NEw, T.R., 1981: A revision of the Australian Nymphidae (Insecta: Neuroptera). Aust. J. Zool. 29: 707-750.

New, T.R., 1983: A revision of the Australian Osmylidae: Kempyninae (Insecta: Neuroptera). Aust. J. Zool. 31: 393 420.

NEw, T.R., 1984: Revision of the Australian Ascalaphidae (Insecta: Neuroptera). Aust. J. Zool. Suppl. 100: 1-84.

New, T.R., 1985a: A revision of the Australian Myrmeleontidae (Insecta: Neuroptera). I. Introduction, Myrmeleontini, Protoplectrini. Aust. J. Zool. Suppl. 104: 1-90.

New, T.R., 1985b: A revision of the Australian Myrmeleontidae (Insecta: Neuroptera). 11. Dendroleontini. Aust. J. Zool. Suppl. 105: 1-170.

NEW, T.R., 1985c: A revision of the Australian Myrmeleontidae (Insecta: Neuroptera). III. Distoleontini and Acanthaclisinae. Aust. J. Zool. Suppl. 106: 1-159.

New, T.R., 1988: A revision of the Australian Hemerobiidae (Insecta: Neuroptera). Invertebr. Taxon. 2: 339-411.

New, T.R., 1989a: The Psychopsidae (Insecta: Neuroptera) of Australia and the Oriental Region. Invertebr. Taxon. 2 (1988): 841-883.

New, T.R., 1989b: The genus Oedosmylus (Insecta: Neuroptera: Osmylidae). Invertebr. Taxon. 3: 135-148.

NEw, T.R., 1991: Neuroptera (lacewings). In THE INSECTS OF AUSTRALLA. Melbourne University Press: 525-542.

RIEK, E.F., 1970: Neuroptera (lacewings). In THE INSECTS OF AUSTRALLA. Melbourne University Press: 472-494.

RIEK, E.F., 1974: The Australian moth-lacewings (Neuroptera: Ithonidae). J. Aust. ent. Soc. 13: 37-54.

TillyarD, R.J., 1923: Descriptions of new species and varieties of lacewings (Order Neuroptera, Planipennia) from New Zealand, belonging to the families Berothidae and Hemerobiidae. Trans. Proc. NZ Inst. 54: 217-225.

(accepted 9 August 1991) 